\title{
ENTRY INTO THE OIL REFINING BUSINESS: VERTICAL INTEGRATION RE-EXAMINED*
}

\author{
EUGENE V. ROSTOW† and ARTHUR S. SAGHS ${ }^{\dagger}$
}

IN a study made some years ago, ${ }^{1}$ one of the authors of this article concluded that the petroleum industry structure contained substantial elements of monopoly, as that term is defined by economists ${ }^{2}$ and lawyers; $;^{3}$ that its market performance under present methods of regulation showed distinct symptoms of effective monopoly in pricing, in selling costs and in the determination of output; and that it was legally and technologically feasible to

\footnotetext{
*The authors gratefully acknowledge the information and other aid provided in the preparation of this study by a number of people connected with the oil industry and the government.

†Professor of Law and Member of the Graduate Faculty of Economics, Yale University.

if Third-year student, Yale Law School, and Associate Editor of the Yale Law Journal.

1. Rostow, A National Policy for the OIl Industry (1948). References are to the third printing, which contains certain revisions and corrections of the text. The discussion was carried further by Professor Bain and the author in Bain, Rostov's Proposals for Petroletm. Policy, 57 J. Pot. Econ. 55 (1949); Rostow, A Reply, 57 J. Pot.. ECoN. 60 (1949); and Bain, A Rejoinder, 57 J. PoL. Econ. 68 (1949).

2. The term "monopoly" is used to refer to market situations in which sellers or groups of sellers have a substantial degree of power over the price they charge-significantly more than the price power which sellers would have in "workably" or "effectively" competitive situations. See discussion pp. 860-4 infra.

3. Mandeville Island Farms v. American Crystal Sugar Co., 334 U.S. 219 (1948); United States v. Paramount Pictures, Inc., 334 U.S. 131 (1948) ; Schine Chain Theatres, Inc. v. United States, 334 U.S. 110 (1948) ; American Tobacco Co. v. United States, 328 U.S. 781 (1946); United States v. Aluminum Co. of America, 148 F.2d 416 (2d Cir. 1945) ; United States v. Aluminum Co. of America, 91 F.Supp. 333 (S.D. N.Y. 1950). United States v. Paramount Pictures, Inc., 85 F.Supp. 881 (S.D. N.Y. 1949). Comments on some of these cases appear in Rostow: Monopoly Under the Sherman Act: Powucr or Putrose? 43 ILL. L. Rev. 745 (1949) ; The New Sherman Act: A Positive Instrtment of Progress, 14 U. of CHr. L. Rev. 567 (1947); and Problems of Sisc and Integration in CCH Symposium, Business Practices Under Federal Antitrust Laws 117 (1951). See note 6 infra, and Harbeson, A New Phase of the Antitrust Lawe, 45 Mrcr. L. Rev. 977 (1947); Levi, The Antitrust Lazes and Monopoly, 14 U. of CHI. L. Rev. 153 (1947); Wood, The Supreme Court and a Changing Antitrust Concept, 97 U. of PA. L. REv. 309 (1949) ; Zlinkoff \& Barnard, Mergers and The Antitrust Lazus, The Columbia Stecl Case, The Supreme Court and a Competitive Economy, 1947 Term, 97 U. of PA. L. REv. 151 (1948). For views of economists see Nicholls, Price Policies in tire Cigarette IndusTRY cc. 27-9 (1951); Adelman, Effective Competition and the Antitrust Lazes, 61 Hanv. L. Rev. 1289 (1948); Symposium, 39 Am. Econ. Rev. Supp. 280 (1949); Kaysen, Collusion Under The Sherman Act, 65 Q.J. Econ. 263 (1951); Mason, The Current Status of the Monopoly Problem in the United States, 62 HARv. L. REv. 1265 (1949); Symposiun, 40 Am. Econ. Rev. Supp. 23-104 (1950); Wright, Tozeards Cohercht Alli-Trust, 35 VA. L. Rev. 665 (1949).
} 
seek a more competitive form of organization for the industry, without abandoning the economies of the large scale of production, or other economic advantages. On the contrary, it was thought that a reorganization of the industry in the interest of increasing the degree of competition should eliminate significant wastes associated with its methods. A central finding of that enquiry was that the control of transportation facilities-particularly of pipe lines-by the major oil companies was an important factor in permitting those companies as a group to maintain a material degree of monopoly power over the prices at which they bought crude oil, and sold gasoline and other products. In the setting of the oil industry, it was contended that this form of vertical integration constituted a barrier to the possible entry of new firms into the refining and distribution phases of the oil business.

The purpose of the present paper is to consider whether recent changes in the pipe line sector of the industry require a change in the analysis and conclusions of $A$ National Policy for the Oil Indistry. Under the combined influence of regulation and taxation, pipe line rates have been falling for some

4. Since the preparation of that book, developments in the field of oil production seem to have occurred within the framework of the trends discussed. The basic procedure for limiting crude production to estimates of market demand (at or near prevailing price levels) continues through the cooperative activities of the Department of Interiur and the state production control authorities, in apparent inconsistency with the standards of the Interstate Compact authorizing state conservation legislation. Pub. L. No. 128, 82d Cong., 1st Sess. (Aug. 28, 1951) ; 57 Stat. 383 (1943). A minority of seven members of the House Committee on Interstate and Foreign Commerce wished to insert in the 1951 Joint Resolution approving a renewal of the Compact the requirement that the Attorney General make a continuing study, and at least one annual report a year, on whether state action under conservation laws violated Article $\mathrm{V}$ of the Compact, forbidding price stabilization or fixing, or action to further monopoly or "regimentation." H.R. KEs. No. 854, \$2d Cong, 1st Sess. 3-5 (1951) ; Hearings before Committec on Interstate asd Forcign Commerec oiz H. J. Res. 206, 82d Cong., 1st Sess. (1951). See SeN. Rep. No. 25, S1st Cong., lst Sess. $13-19$ (1949), and, e.g., Dallas Morning News, March 16, 1952, p. 12, col. 1 (oil production cut by Texas Railroad Commission forecast because stocks were high) ; Perham, Turn of the Valve, Barron's, May 5, 1952, p. 3. For recent developments in conservation and other regulatory practices see MURPhy, Conservation of On arid Gas (1949); Hardwicke, Antitrust Laws and the Conseriation of Oil and Gas, 23 Tunn:se L. Rev. 183 (1948); Murphy, The Interstate Confrat to Consere' Oil an:d Gas: An Experiment in Co-operative State Production Control, 17 MIrss. L.J. 314 (1946). The Supreme Court has continued and enlarged its hands-off attitude towards state regulation of oil and gas production that began with Champlin Ref. Co. v. Ollahoma, 226 U.S. 210 (1932). See Cities Service Gas Co. v. Peerless Oil \& Gas Co., 340 U.S. 179 (1950); Phillips Petroleum Co. v. Oklahoma, 340 U.S. 190 (1950) (Oklahoma natural gas price fixing regulations upheld on conservation grounds against due process attacl; no mention of possible conflict of state laws with compact defining permissible standards for their administration, and inadequate consideration of such state action as a burden on or a discrimination against interstate commerce). Recent decisions indicate that issues arising under interstate compacts will be considered federal questions for jurisdictional purposes. West Virginia v. Sims, 341 U.S. 22 (1951); Delaware River Joint Toll Bridge Commission v. Colburn, 310 U.S. 419 (1940) (Supreme Court will take appellate jurisdiction over cases involving interpretation of interstate compacts); Dunbar, Interstale Compacts 
years, a time when other transportation costs have been rising. ${ }^{5}$ Despite some recent increases, pipe line rates have probably risen less in the last few years than other transportation costs and charges. And they have now been

and Congressional Consent, 36 VA. L. Rev. 753 (1950). The reasoning of such cases should, in appropriate situations, overcome Burford v. Sun Oil Co., 319 U.S. 315 (1943).

Unitization has made a good deal of progress in recent years, both at the level of thought, Hardwicke, Antitrust Laws et al. v. Unit Operation of OtL or Gas Pools (1948); Dow, The Oil Compact as an Impetiss for Sound Conservation Practices, 24 Rocky Mr. L. Rev. 154 (1952) ; Errebo, Unit Operation at Colton Valley: An Allegcd Violation of the Sherman Act, 24 TUlane L. REv. 76 (1949); Hardwicke, Unitization Statutes: Voluntary Action or Compulsion, 24 Rocky MT. L. REv. 29 (1951); Jacobs, Unit Operation of Oil and Gas Fields, 57 Y ALE L.J. 1207 (1948) ; Kaveler, The Engincering Basis for and the Results from the Unit Operation of Oil Pools, 23 TULANE L. RLv. 331 (1949) ; King, Pooling and Unitization of Oil and Gas Leases, 46 Micn. L. REv. 311 (1948) ; Myers, Spacing, Pooling and Field-Wide Unitizationt, 18 Mrss. L.J. 267 (1947); Moses, The Lonisiana Department of Conservation, 5 Southwestern L.J. 170 (1951); Voorhees, Techniques of Field-Wide Unitization, 24 RockY MT. L. Rev. 14 (1951); and at the level of action, LA. Rev. Stat. tit $30 \$ 10$ (1951); OkLA. Stat. ANN. tit. 52, §287.1 et seq. (1951) ; ARK. Stat. \$53-115 (1951 Cum. Supp.) ; N. Mex. Stat. ANN. § 8-1138 (1951 Cum. Supp.); Wro. Comp. Stat. \$\$ 57-113, 114 (1951 Cum. Supp.). The courts have in general been favorable to unitization plans. Palmer Oil Corp. v. Phillips Petroleum Co., 204 Okla. 543, 231 P.2d 997 (1951) (unitization act, subsequently repealed, sustained against charges of unreasonableness, invalid delegation of legislative powers, and interference with contractual obligations), appealed sub nom. Palmer Oil Corp. v. Amerada Petroleum Corp., 20 U.S.L. WEEk 4317 (U.S. May 13, 1952) (appeal dismissed for want of "any substantial federal questions"); West Edmond Hunton Lime Unit v. Stantind Oil \& Gas Co., 193 F.2d 818 (10th Cir. 1951); Railroad Commission v. Sterling Oil \& Refining Co., 147 Tex. 547, 549, 218 S. W. 2d 415 (1949) (order prohibiting production of either oil or gas unless "all of the gas produced incident to such production is made available for one or more of the lawful uses" sustained as reasonable); Everett v. Phillips Petroleum Co., 218 La. 835, 51 So.2d 87 (1950) (compulsory drilling tunit statute does not violate "any provision of either the state or federal Constitution"). But cf. Dobson v. Arkansas Oil \& Gas Commission, 218 Ark. 160, 235 S.W.2d 33 (1950) (in the absence of legislation, commission has no power to compel unitization); Pickens v. Ryan Consol. Petroleum Corp., 219 S.W. 2d 150 (Tex. Civ. App. 1949) (Railroad Commission has no power to forec pooling agreement upon unwilling owners). This advance in the conservation of underground pressure, and of steel, may be having some adverse effect on the competitive character of crude markets. See Rostow, op. cit. supra note 1, at 120 . See also Complaint in United States v. Cotton Valley Operators Committee, 75 F.Supp. 1 (W.D. La. 1948), 77 F.Supp. 409 (W.D. La. 1948), Complaint dismissed when Government refused to produce documents, Civil No. 2209, W.D. La., Sept. 20, 1949, aff'd by equally divided Court, 339 U.S. 940 (1950). See generally, Williams, Conservation of Oil and Gas, 65 HAkv. L. REv. 1155 (1952).

5. Rates dropped consistently from 1933 to 1948 in response to: (1) Changes in the tax laws, Reduced Pipe Line Rates and Gathering Charges, 243 I.C.C. 115, 127, 139 (1940); (2) ICC decisions, Reduced Pipe Line Rates and Gathering Charges, 243 I. C.C. 115 (1940); Petroleum Rail Shippers' Assn. v. Alton \& Southern R.R., 243 I.C.C. 589 (1941); Minnelusa Oil Corp. v. Continental Pipe Line Co., 258 I.C.C. 41 (1944); and possibly (3) Competing forms of transportation, Wolbert, AMerucan Pipe Linrs 16 (1952). Thus in 1948 the ICC was able to state in regard to 69 major rates that "current rates show[ed] an average decline of 17.7 cents per barrel under the rates in effect on December 31, 1933, or an average rate reduction of 43.2 per cent." Reduced Pipe Line 
held at a relatively low level long enough to permit some tentative inferences as to their significance in impeding the competitively favorable entry of new firms, especially in the refining and marketing stages of the oil business.

\section{Some Economic Assumptions}

These changes in the industry, and the prolific recent re-examination of antitrust policy, ${ }^{B}$ suggest not only a review of the analysis of the earlier

Rates and Gathering Charges, 272 I.C.C. 375, 381 (1948). Talking as typical the rates between the Mid-Continent field and Chicago, the ICC noted a reduction from 46 cents per barrel in 1933 to 40 cents, $38 \mathrm{x} / 2$ cents, $34 \mathrm{I} / 2$ cents, 30 cents and finslly 25 cents in 1948 . "Gathering line rates similarly [had] become rather stabilized on a basis approsimately 50 per cent of the rates in effect on December 31, 1933." Ibid.

6. See notes 3 supra; 9, 11, 1s infra; Adams, Dissolution, Dirorcentent, Dizestiture; The Pyrrhic Victories of Antitrust. 27 Ind. L.J. 1 (1951); Adelman: Business Size ard Public Policy, 24 J. Bus. 269 (1951) ; Integration and Antitrust Policy, 63 Hanv. L. Rev. 27 (1949) ; Effective Competition and the Antitrust Latus, $61 \mathrm{HARv.} \mathrm{L.} \mathrm{REv.} 1289$ (1949); Is Big Business Getting Bigger? Fortune, Jan. 1952, p. 59; Antilrust Upside-Douts Cale and Eat It Too, Fortune, March 1950, p. 57; The A \& $P$ Case, $A$ Study is Asplicd Economic Theory, 63 Q.J. Econ. 23S (1949); Bain, Worhable Comprtition iss Oligopoly: Theoretical Considerations and Some Empirical Evidenee, 40 Ass. Ecow. REx. Surp. 35 (1950) ; Berge, Problens of Enforcenest and Interpretation of the Slicrnas: Act, 38 A2s. Econ. Rev. Supp. 172 (1948) ; Blair, Technology and Size, 38 Axr. Ecori. Rev. Surp. 121 (1948) ; Callmann, Essente of Anti-trust, 49 CoL. L. Rev. 1100 (1949); Chadwell \& MicLaren, The Cutrrent Status of the Antitrust Lazus, [1950] InL. Lsw Fonves 491; Chandberlin, The Theory of Monopolistic Conppetition (5th ed. 1946); Carlston, Antitrust Policy: A Problem in Statccraft, 60 Yale L.J. 1073 (1951); Chank, AltersNATIVE to Serfoosi (1948); Clark, Tou'ard a Concept of Workable Conspctition, 30 A:s. Econ. Rev. 241 (1940); Dirlam \& Kahn, Antitrust Lau and the Big Buycr: Anolker Look at the A \& P Case, $60 \mathrm{~J}$. Poz. Econ. 118 (1952); Drucker, How Big is 100 Big?, Harpers, July 1950, p. 23; Edwards, Maintaining Cosmetirion (1949); Edwards, Pub-

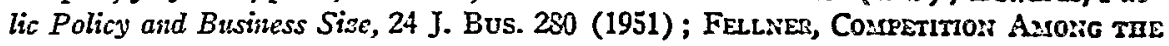
Few (1949); Fleming, Ten Thousand Couranandarents (1951) ; Fuchs, Ecomomic Considerations in the Enforcentent of the Antitrust Laus of the United States, 34 Mrnis. L. Rev. 210 (1950) ; Hale, Vertical Integration: Impact of the Antitrust Lacus Ufon Combinations of Successize Stages of Production and Distribution, 49 COL. L. REv. 921 (1949); Hale, Siee and Shape: The Individual Enterprise As a Monopoly, [1950] Irt. LAw ForuM 515; Hefleblower, Econonics of Size, 24 J. Bus. 253 (1951); Johnston \& Stevens, Monopoly or Monopolization-A Reply to Professor Rostow, 44 ILL, L. REv. 269 (1949) ; Lasky, Metaphysics a. Reality in Antitrust Law, 26 CALIF. S.B.J. 23 (1951); Latham, Giantisn and Basing-Points: A Political Analysis, 58 YALE L.J. 383 (1949); Latham, Lannent For Centent: Being an Anwer to Reply, 58 YALE L. J. 1079 (1949); Marcus, Civil Rights and the Antitrust Lawes, 18 U. of CHL. L. Rev. 171 (1951); MIcAllister \& Quigg, The Art of Selecting and Exploiting Half Truths-A Reply to "Giantism and Basing-Points," 58 Yale L.J. 1068 (1949) ; Markham, An Alternatize Approaeh to the Concept of Workable Competition, 40 Aur. Econ, Rev. 349 (1950) ; MIArruns, Cossperrtro:: IN THE RAyon Industry (1952) ; Meriam, Bigness and the Economic Analysis of Competition, 28 Harv. Bus. Rev. No. 2, 109 (1950); MIllleb, Unfaur Cosupetimo: (1941); New York State Bar Assoctation, Section on Antitrust Law, Letter uf Trasis-

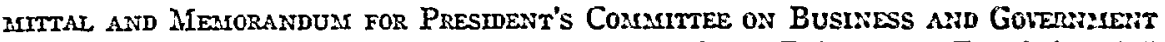
Relations (1950); Oppenheim, A New Look at Antitrust Enforeement Trends in CCH 
study, in the light of present conditions, but a fuller statement of the assumptions on which it was based. Perhaps a further reason for such a course is the chronic difficulty of communication between economists and lawyers, and between students of both these disciplines and the rest of the public. These are of course common tribulations in the life of a specialist; but they must be tackled and overcome somehow, in the interest of informed public debate. Even if all technical monographs were clearly written-which is hardly the case-what lies behind them could not always be apparent to a non-technical reader. Using the shorthand of specialized language is surely one of the constitutional privileges of scholarship. And it would in any event be impossible to load every professional paper with a full account of all that came before. These bleak if inevitable features of technical writing create an unfortunate gap between the professional and the non-professional vocabulary on many matters of public concern. While no layman expects to understand a journal article on physics or surgery, he has some reason to believe that he knows what is meant when he reads about "monopoly" or "competition." Unhappily, however, these words of ordinary speech may-and usually do-mean quite different things to lawyers, economists, and the general reader.

First of all, it was taken for granted in the earlier study-and subsequent decisions require no change in the assumption-that the object of the antitrust laws is to achieve what may be called a "workably" or "effectively" competitive organization of industry and commerce, and not "pure" or "perfect" competition. ${ }^{7}$ Correspondingly, it was-and is-assumed that the idea

Symposium, A New Look at Antitrust Enforcentent Trends 69 (1950); Rahl, Conspiracy and the Antitrust Laws, 44 ILL. L. REv. 743 (1950) ; Smith, Effcctive Competition: Hypothesis for Modernizing the Antitrust Lazus, 26 N.Y.U. L. Rev. 405 (1951); Spengler, Vertical Integration and Antitrust Policy, 58 J. Poz. Ecos. 347 (1950) ; STock: ing \& Watkins, Monopoly and Free Enterprise (1951); Sunderland, Changing Legal Concepts in the Antitrust Field, 3 Syracuse L. Rev. 60 (1951) ; Comment, Verlical Intcgration in Aluminum: A Bar to "Effective Competition," 60 Y ALE L. J. 294 (1951); Note, The Colunbia Steel Case: New Light on Old Antitrust Problems, 58 Y ALE L. J. 764 (1949) ; Comment, Price Systems and Competition: The Basing-Point Isstes, 58 YALE L.J. 426 (1949); Note, Trouble Begins in the "New" Sherman Act: The Perplexing Story of the $A \& P$ Case, 58 Yale L.J. 969 (1949); Note, Sherman Act and Close-knit Combinations -an Efficiency Test, 43 ILt. L. Rev. 523 (1948); Note, United States Stcel's Westzuarl March: A Chain Reaction of Concentration, 1 STAN. L. REv. 108 (1948). Of the very recent material, see also Lilienthal, Our Anti-Trust Lawes Are Crippling Anterica, Collier's, May 31, 1952, p. 15; Stigler, The Case Against Big Business, Fortune, May 1952, p. 123. Special note should also be taken of Schueller's historical re-examination of certain antitrust concepts, The New Antitrust Illegality Per Se: Forestalling and Patent Misusc, 50 CoL. L. REv. 170 (1950).

7. Rostow, op. cit. supra note 1 , at xiii, $103,125-6$ and exchange with Bain, supro note 1. See discussion pp. 893-4 infra and economic materials cited in note 6 supra. See also Fellner, Competition Among the Few 282 et seq. (1949); Adelman, Effective Competition and the Antitrust Lazes, 61 HARv. L. Rev. 1289, 1298-1304 (1948). For recent statements of this view and its application to other industries consult MARKuAM, Conpettition in the Rayon Industry 191-212 (1952); Nicholls, Price Policies in tue Cigarette Industry (1951); Tennant, The American Cigarette Industry (1950). 
of workable or effective competition is the main component of the rule of reason in defining the offenses under Sections 1 and 2 of the Sherman Act. ${ }^{8}$

For a variety of social, political and economic reasons which lie deep in our history, the antitrust laws operate as a pervasive influence against monopoly and unreasonable restraints of competition in the structure and conduct of the economy. Their administration, however, is and must be dominated by a practical sense of what can be achieved, given the technological and historical elements in a particular situation. Case by case, the pattern is pricked out, fulfilling the somewhat different economic philosophies which different groups of judges read into the broad language of the Sherman Act and its subordinate statutes.

The judicial norm is now close to what the economists have classified as workable competition." As Professor Stigler defines the term, "an industry is workably competitive when (1) there are a considerable number of firms selling closely related products in each important market area, (2) these firms are not in collusion, and (3) the long-run average cost curve for a new firm is not materially higher than for an established firm." The first two points, Stigler adds, "serve to eliminate not only monopoly and explicit collusion but also tacit avoidance of price competition for fear of retaliation of close rivals. . . . The third point excludes direct and indirect controls of entry of new firms."10 Other definitions put the emphasis somewhat diferently, ${ }^{11}$ but turn on the same crucial elements-the capacity of buyers to take advantage of rivalry among sellers, the inability of sellers to exercise appreciable control over the price at which they sell, and the absence of cost or other barriers to the entry of new firms. ${ }^{12}$ While these criteria are a far

8. See Rostow, Monopoly Under The Sherman Act: Poaicr or Purpose?, 43 ILx. L. Rev. 745, 791 (1949) ; Rostow, Problems of Size and Integration in CCH Srapostuss, Bustness Practices Under Federal Antitrust Laws 117 (1951).

9. United States v. Columbia Steel Co., 334 U.S. 495, relicaring denicd, 334 U.S. 862 (1948); United States v. Paramount Pictures, 334 U.S. 131 (1948); United States v. Aluminum Co. of America, 91 F.Supp. 333 (S.D. N.Y. 1950); United States v. Paramount Pictures, 85 F.Supp. 881 (S.D. N.Y. 1949); Mason, The Currest Status of the Monofoly Problem in the United States, 62 Harv. L. Kev. 1265, 1272 (1949); Nicuous, Pric: Policies in the Cigarette Industry c. 28 (1951); MicDonough \& Winslow, The Molion Picture Industry: United States 2. Oligopoly, I Stax. L. Rev. 385 (1949); Srocrsma \& 'Vatkins, Monopoly and Free Enterprise c. 9 (1951) ; Edwands, Mlalitisinisg Co:sPETITION 15 (1949).

10. Stigler, Extent and Bases of Monopoly, 32 Ax. Ecor. Rev. Supp. No. 2, pt. 2, pp. 1, 2-3 (1942). This comment may cure an admitted defect in Rosrow, op. cil. sispro note 1, pointed out by Professor Stigler in Book Review, 57 YALE L.J. 1322 (1948).

11. See Clark, Tou'ard A Concept of Workable Competition, 30 Ass. Ecos. REv. 241, 243 (1940) ; Edwards, Maintaining Cosrpettrion 9, 10 (1949); Galdraitu, Asseruca: Capitairsa-The Concept of Countervailme Power c. 9 (1952); Bain, A vole on Pricing in Monopoly and Oligopoly, 39 Asr. Ecos. Rev. 448 (1949); Bain, Relotion of Profit Rate to Industry Concestration, 65 Q.J. Econ. 293 (1951).

12. Workable competition implies chiefly that there be "a fairly large number of sellers and buyers, no one of whom occupies a large share of the market, the absence of 
cry from the assumptions which define the cases of pure and perfect competition, they would assure society many of the advantages which economists have always found in the process of competitive adjustment: movements of capital towards activities where higher profits can be earned, so that through time, changes in supply would drive price towards the level of average longterm costs, including an average or "normal" return on capital.13

The test of workable competition, with its equal emphasis on market structure and market behavior, provides a useful approach to the economic side of antitrust problems. In the setting of antitrust litigation, the courts can never lose sight of the fact that they are reviewing the behavior as well as as the structure of an industry or a market, and that they must review its operations over a period of time. A pattern which may be evidence of noncompetitive behavior in one setting may well demonstrate effective competition in another. As Professor Markham has pointed out, the concept of workable competition as an instrument of public policy should not get far away from the possibilities of effective remedial action. He therefore concludes that "an industry may be judged to be workably competitive when, after the structural characteristics of its market and the dynamic forces that shaped them have been thoroughly examined, there is no clearly indicated change that can be effected through public policy measures that would result in greater social gains than social losses."14

Secondly, it was assumed in A National Policy for the Oil Industry-and again subsequent developments do not require a modification of the hypothesis -that the antitrust laws do not and cannot discriminate among companies on the basis of their "progressive" performance. Dean Mason has proposed that the antitrust laws be reinterpreted to judge the legality of business arrangements not only from the point of view of workable competition, but of business performance as well. He lists these ideas as the principal components of the concept of progressive performance:

"1. Progressiveness: are the firms in the industry actively and effectively engaged in product and process innovation?

2. Cost-price relationships : are reductions in cost, whether due to falling wages or material prices, technical improvements, discovery of new sources of supply, passed on promptly to buyers in the form of price reductions?

3. Capacity-output relationships: is investment excessive in relation to output?

collusion among either group, and the possibility of market entry by new firms." Mason, The Current Status of the Monsopoly Problem in the United States, 62 HaRv. L. Rev. 1265, 1268 (1949).

13. Marshall, Principles of Economics bk. 5 (8th ed. 1930); Pigou, The EcoNOMICS OF Welfare pt. 2 (3d ed. 1929).

14. Markham, An Altemative Approach to the Concept of Workable Competition, 40 Am. Econ. Rev. 349, 361 (1950). See also Markand, Competition in the Rayon INDUSTRY cc. 6, 10 (1952). 
4. The level of profits: are profits continually and substantially higher than in other industries exhibiting similar trends in sales, costs, innovations, etc.?

5. Selling expenditures: is competitive effort chiefly indicated by selling expenditures rather than by service and product improvements and price reductions?

"No one familiar with the statistical and other material pertaining to the business performance of firms and industries would deny the extreme difficulty of constructing from this material a watertight case for or against the performance of particular firms in particular industries. Few, on the other hand, would deny that with respect to many industrial markets an informed judgment is possible. For example, it is possible from the record of the last two decades to determine that the performance of the automobile industry is relatively good, despite the existence of a small number of firms, while the performance of the construction industry is relatively bad. ${ }^{15}$ In any case, it is on the basis of just such industry data as we are now discussing that a decision even under the market structure test would have to be made whether the number of alternatives available to buyers or sellers in a particular industrial market is or is not 'adequate.' "16

While there is much in Mason's analysis which should influence the Department of Justice or the Federal Trade Commission in their choice of cases, it should not become part of the "rule of reason" under the antitrust laws. The belief that the antitrust laws distinguish "good" from "bad" trusts is well-established in popular opinion. ${ }^{17}$ Some lawyers have not only advocated such a change, ${ }^{18}$ but have even read the cases to imply that it has

15. It should be noted in qualification of Dean MIason's judgment about the automobile industry that no new firm has succeeded in entering the industry, except for the KaiserFrazer venture, since Chrysler's start in 1925. F.T.C., Repost on Jiotos Vericle I:voustnY 28 (1939). Moreover the much-abused construction industry, criticized perhaps as often on aesthetic as on economic grounds, may merely be suffering from the increase in relative costs afficting all crafts (such as domestic service) in which the effective use of capital (and, therefore, the productivity of labor) has advanced less than in the bulls of industry. With wage levels set by far more capital-intensive industries, and then somewhat exaggerated by the building trades unions, construction will continue to seem expensive until some one discovers effective methods of using as much capital per worker as, say, farming or coal mining. Query, therefore, whether its problems are primarily structural or technological.

16. Mason, The Current Statis of the Monopoly Problenn in the United Stales, 62 Harv. L. Rev. 1265, 1281-2 (1949). See also Kreps, Mreasumearent of the Seetal Persforarance of Business (TNEC Mionograph 7, 1940).

17. See, e.g., Burck, The Jersey Company II: Its Affiliates in Practice, Fortune, Oct. 1951, p. 105; Wilson, Is Big Business Bad?-Fact 2. Fiction (reprint of specch before Antitrust Symposium of Chicago and Illinois Bar Associations, Chicago, Ill., Jan. 18, 1952).

18. Kales, Contracts and Coxrbinations in Restrannt of Trade \$ 62 (1918); Smith, Effective Competition: Hypothesis for Modernizing the Antitrust Law, 26 N.Y.U. L. Rev. 405 (1951). Cf. Callmann, The Essence of Anti-trust, 49 CoL L. Rev. 1100 (1949); 
taken place. ${ }^{19}$ For reasons more fully stated elsewhere, we do not believe that this standard belongs or should belong among the judicial rules used in applying the antitrust laws. ${ }^{20}$ It would be incompatible with the considerations dominating the decision of the Trenton Potteries case, ${ }^{21}$ which go back at least to Lord Mansfield, ${ }^{22}$ and, according to Coke, ${ }^{23}$ to ancient versions of the common law.

To decide antitrust cases on the basis of an evaluation of the defendant companies' "progressiveness" would be entirely inconsistent with the main stream of Sherman Act interpretation, and entirely impractical. Prices, research practice, innovation and managerial skills which were progressive at the time of litigation could become sluggish and passive. The theory of the antitrust laws is that the pressure of a reasonable degree of competition is the force on which society can most safely rely to keep business performance progressive. Competition does not always work to achieve this end. And some monopolies and near-monopolies are managed with great drive and progressiveness. Nonetheless, judicial action under the antitrust laws, as a matter of judicial administration as well as of doctrine, cannot go beyond the issues of workable competition in market structure and market behavior. To follow the course recommended by Dean Mason would make the federal courts, rather than unregulated markets, our chief social institution for allocating resources and guiding production.

Wright, Towards Coherent Anti-Trust, 35 VA. L. Rev. 665 (1949); Wright, Some Pitfalls of Economic Theory as A Guide To the Law of Competition, 37 VA. L. Rev. 1083 (1951).

19. Really only one case, United States v. Aluminum Co. of America, $91 \mathrm{~F}$. Supp. 333 (S.D.N.Y. 1950), which we do not believe in any event can be interpreted in this sense. Rostow, Problems of Size and Integration, infra note 20, at 123-6, 129. Wolueur, American Pipe Lines 65, 77, 88-9, 99, 107 (1952) ; Oppenheim, Divestiture as a Remtedy Under the Federal Antitrust Lazes, 19 GEo. WASH. L. Rev. 2, 10-12 (1950); Oppenheim, A New Look at Antitrust Enforcement Trends in CCH SyMposium, A NEw Look aT Antitrust Enforcensent Trends 69 (1950). See also Smith, Effective Competition: Hypothesis for Modernizing the Antitrust Law, 26 N.Y.U. L. REv. 405 (1951).

20. Rostow, Problems of Size and Integration in CCH Symposiun, Business PRACtices UNDER Federal AntTtrust Laws 117, $132-4$ (1951); for a fuller discussion see Rostow, Market Organization and Stabilization Policy in Incone Stumluzatron ron a Devezoptng Dearocracy, edited by Millikan and soon to be published by the Yale University Press. See also, Adelman, Business Size and Public Policy, 24 J. Bus. 269, 273 (1951); Hefleblower, Economics of Size, 24 J. Bus. 253 (1951); Wright, Some Pilfalls of Economic Theory as a Guide to the Lane of Competition, 37 VA. L. REv. 1083, 1093 (1951). For some indication of the trend of recent antitrust law enforcement consult H.R. REP. No. 3236, 81st Cong., 2d Sess. (1951).

21. United States v. Trenton Potteries, 273 U.S. 392 (1927).

22. " $[I] f$ any agreement was made to fix the price of salt . . . by people dealing in that commodity, the court would be glad to lay hold of an opportunity, from zuhat quarter soever the complaint came, to shew their sense of the crime; and that at what rate soever the price was fixed, high or low, made no difference, for all such agreements were of bad consequence, and ought to be discountenanced." King v. Norris, 2 KENY. 300 (1758).

23. 3 Co. Litr. c. 89. 


\section{Combination, Vertical Integration and ANtitrust Policy}

A preliminary question which arises in considering the possible application of the antitrust laws to the problems of an industry containing a considerable number of firms is whether the separate market influence of a group of the larger firms can be treated collectively. Can the major oil companies in any market be considered to have pooled their market power, by participating in well understood programs of price-making through price leadership, or by other actions which would support the judicial conclusion that they have combined?

Several recent cases have reviewed the circumstance under which a relatively small number of large sellers in a market will be deemed to have combined (or even "conspired") for purposes of the Sherman Act."2 They give almost decisive weight to inferences of combination from the kind of closely parallel behavior which would represent the intelligent response of such sellers to their self-interest within the framework of the relevant market. ${ }^{25}$ Open price competition offers little or no advantage to the large seller in a market "of the few." Competition "among the few" rarely takes the form of direct price rivalry. Usually, in such cases, there has been some showing that the normal drives of oligopoly have been disciplined or refashioned, to minimize uncertainty about the policy of rivals, or to achieve somewhat more profitable results than might obtain under conditions of unorganized oligopoly.

24. See, e.g., United States v. Paramount Pictures, Inc, 334 U.S. 131 (1948); FTC v. Cement Institute, 333 U.S. 683 (1948); American Tobacco Company v. United States, 328 U.S. 781 (1946) ; Goldman Theaters v. Loew's, Inc., 150 F.2d 738 (3rd Cir. 1945); Interstate Circuit, Inc. v. United States, 306 U.S. 208 (1939) ; Mrilgram v. Loew's, Ine, 192 F.2d 579 (3d Cir. 1951). But see Fanchon \& Miarco v. Paramount Pictures, Ine, 100 F. Supp. 84 (S.D. Cal. 1951) ("[N]o parallelism, conscious or unconscious, can overcome a finding of reasonableness." Id. at 104). Clark, Disctission, 40 As. Ecost. Res. SUPP. 103 (1950) ("I am not asking for a requirement that overt collusion be proved and would like to de-emphasize the issue of collusion rather than do anything to increase its importance. Secret collusion can reasonably be inferred from overt conduct; but the present doctrine seems to have gone far beyond this. ... [T] rade practices that impair competition should be subject to correction whether or not any actual collusion enters in."). See also Nicrolis, op. cit. supra note 9, at c. 26, 423.

25. See generally Chasiberlin, The Theory of Monopolistic Cosiretit7osi 31-55 (3d ed. 1938); Fellner, Contpetition Assong the Few (1949) passim; Stoctisag \& Watkins, Monopoly and Free Enterprise 85-131 (1951). For a cuncise analysis of price formation in the cement industry see Comment, 58 YALE L.J. 420, 432-3 (1949). For a summary description of market forms see Wrcox, CoMpetimion nxD Mo:roroly n:: AMrERICAN INDUSTRY (TNEC Mfonograph 21, 1940): Fly, Olseriations on the Anti-lrust Lawes, Economic Theory and the Sugar Institute Decisions: I, 45 YALE L.J. 1339 (1936); Wolbert, Aurerican Pipe Lines 59-6S (1952).

It is this body of thought, based on the work of earlier ecunomists, which has introduced the cumbersome words "oligopoly" and "oligopsony" into the legal discussion of market problems. This process, which has been going on at least since Mr. Fly's articlss on the Sugar Institute case, supra, has provoked some natural irritation, but no une has yet invented a more convenient way for referring to the characteristies of markets largely occupied by a few large sellers or buyers. 
While it has been possible in some cases to rebut the inference of combination by an affirmative showing of price competition, or other aggressive forms of competition, ${ }^{26}$ the tendency has been to reach conclusions of combination to a marked extent from evidence at least of conscious parallelism, especially with regard to pricing, uniformity of contract terms, and the like. ${ }^{27}$ Professor Dession urges that some separate evidence be produced in these cases that the parallelism be definitely "conscious." "Elusive as the distinction may be," he says, "a firm insistence that the minimum measure of privity between the defendants must be proved by clear and convincing evidence is the sole protection of defendants against a finding of guilt by unproved association." 28 It is hardly possible to generalize as to the quantum and character of the evidence required to connect an individual or an individual company with a general industry-wide combination, of the types considered in the Tobacco ${ }^{29}$ or Paramount ${ }^{30}$ cases. However, cases of this kind, and more emphatically the basing-point cases under the Federal Trade Commission Act, ${ }^{31}$ while they may involve guilt without direct association, do not involve guilt without the effective combination or pooling of market power. The cooperative use of market power is the essence of the proof

26. See, e.g., Tag Mfrs. Institute v. FTC, 174 F.2d 452 (1st Cir. 1949) (price fixing allegations disproved by evidence of widespread deviations from listed prices).

27. See cases cited note 24 supra.

28. Dession, The Trial of Economic Issues of Fact: I, 58 YALE L.J. 1019, 1042 (1949).

29. American Tobacco Co. v. United States, 328 U.S. 781 (1946).

30. United States v. Paramount Pictures, Inc., 334 U.S. 131 (1948).

31. FTC v. Cement Institute, 333 U.S. 683 (1948); Milk and Ice Cream Can Institute v. FTC, 152 F.2d 478 (7th Cir. 1946); Fort Howard Paper Co. v. FTC, 156 F.2d 899 (7th Cir. 1946), cert. denied, 329 U.S. 795 (1946) ; U.S. Maltsters Assu. v. FTC, 152 F.2d 161 (7th Cir. 1945); Salt Producers Assn. v. FTC, 134 F.2d 354 (7th Cir. 1943). Cf. Corn Products Refining Co. v. FTC, 324 U.S. 726 (1945) ; FTC v. Staley Mfg. Co., 324 U.S. 746 (1945) (basing-point system a violation of the Robinson-Patman Act).

32. For recent field studies of gasoline markets, see Dirlam \& Kahn, Leadership and Confict in the Pricing of Gasoline, 61 YALE L.J. 818 (1952), and Brown, op. cit. infra note 120. In Pricing of Gasoline: A Case Study, 26 Harv. Bus. Rev. 723 (1948), Professor Learned examined the pricing practices of the Standard Oil Company (Ohio) for the period from 1937 through 1947. His useful and detailed study of the relatively competitive Ohio area, served by 7 other majors, and several important independents, as well as a fringe of smaller independents, clearly describes the pricing experience of the market during periods of depression and prosperity, price wars and price stability. The Standard Oil Company (Ohio) is classified as the price leader of the market, relatively passive, id. at 750, in its response to trends, interested in price stability, opposed to price cutting, and aiming, after some painful experience, at a relatively low price, among other reasons, because of its awareness of the possibility that higher prices might attract other suppliers and supplies into its territory. Professor Learned believes that Standard Oil Company's (Ohio) limited but real power to control prices, within at least a substantial range, "scems to have prevented gasoline prices from spiraling as much as many so-called free priccs" in the post-war period. Id. at 755-6. Somewhat inconsistently, he also contends that the 
of combination in the Tobacco and Paramount cases. The analysis underlying these cases directs attention to the structure of the industries, the way in which prices are formed, and the barriers to the entry of new firms. Where the legal issue is whether in fact economic power has been used collectively, the best evidence should be an economic demonstration that it has.

It is not within the scope of this article to consider whether in fact the major oil companies combine their market power, consciously or unconsciously, so as to justify their being considered collectively under Section 1 or 2 of the Sherman Act. However, all studies of price formation and of price behavior in the markets for gasoline agree that patterns of price leadership prevail, ${ }^{32}$ and that practices with regard to discounts and the other

administered price of gasoline in Ohio cannot be maintained except at competitive levels. $I d$. at 756. While he would not defend all administered prices, he contends that price results in Ohio are socially sound, although he makes no effort to evaluate distribution costs. He concludes that the managers of the company are not devils, but "sincere, responsible businessmen dealing with many difficult, complex and often intangible problems." Itid.

Hansen \& Niland, Esso Standard: A Case Study in Pricing, 30 Hans. Bus. Rev. 114 (1952) covers the same ground in another market, concluding that Esso exercised its conceded power over price in what the authors regard as a socially constructive way, by keeping market price in 1947-1948 below what the market would have paid. A valuable recent study of the exceptionally aggressive Los Angeles gasoline marliet, Cassady \& Jones, The Nature of Cosipetition n Gasolme Distminution at tere Retatl Lever, A Study of the Los Angeles Market Area (1951), emphssizes the importance of large-scale independent sellers, especially those who use mass-merchandising techniques, and price-cutting, in producing the intermittent price-war atmosphere of that market. These merchants are so numerous, and their access to product so feasible for reasons of geography, that the major companies cannot safely refuse to sell them gasoline, to be resold either as major-company secondary brands or as the price-cutters' own brands. The authors find that the major companies, as elsewhere, put the stress on other than price-competitive devices in their attempts to attract patronage, and talke a substantial interest in the marketing activities of their dealers, over whom they exert considerable influence in regard to product, brand, sales-methods, price, equipment, layout and often even location. In short, they conclude, "the supplier companies recognize their position in the market and operate in such a way as to maximize results." Id. at 108. In Los Angeles, however, confronting a significant volume of competition from independents who offer substantial price concessions, the major companies have had to adjust grice levels defensively. The independent sellers, who have sold as much as 43.6 per cent of the gasoline in the Los Angeles area, as compared with an average of 18.2 per cent for the state as a whole, id. at 107, are normally dependent for success upon the fact that they are not tied to any one supplier, and can therefore buy at "rock-bottom" prices, id. at 127, usually obtaining their supplies from independent sources, sometimes indirectly from major companies. Id. at 123, 126-7, 133, 138-9, and c. 9, passim.

There is, of course, a wide difference in terminology among those who analyze markets, often stemming from policy preferences, as well as from differences in professional habits. Cassady and Jones, for example, regard independent price-cutting vendors as "parasites," id. at 217 , but describe their influence, id. at 97 , as the only force capable of modifying the conservative price-leadership techniques of the major companies and their subsidiaries, which have resulted, in Los Angeles as elsewhere, in the over-building of stations, high costs of distribution, and a sticky price system. The resulting market pattern, hwwever. which is identical with that described many times by others, they label vigorously cum- 
price terms of sales contracts are at least nominally uniform. ${ }^{\text {s3 }}$ There has been little change in the way in which crude markets work. Production is limited by law in most states, and price posting-within the limits of present ceilings-operates as it has in the past, to keep prices relatively high, encouraging sales to major companies, and putting independent refiners at some cost disadvantage, compared with companies which produce a large part of their own supplies. While some gasoline markets show a good deal of instability, and are sensitive to "price wars" and other manifestations of price pressure, field enquiries reveal the familiar picture of oligopoly pricing, marked by high advertising and other selling costs, clear price leadership (sometimes qualified by secret price discrimination), ${ }^{84}$ and strentous efforts to organize distribution in ways which permit price discipline.96 Evidence of this kind has been important in establishing combination as well as "intent" for purposes of the Sherman Act. It may or may not be sufficient in particular cases, depending on many circumstances. Certainly defendants must be linked to the alleged combination. In many Sherman Act cases of loose association, individual defendants have been able to obtain dismissals on the ground that they did not act with the requisite knowledge (or consciousness) of the pur-

petitive, id. at 212, without specifying whether they mean "perfectly" competitive, "cffectively" competitive, "monopolistically" competitive, or any other variant of the term.

In Dynamic Competition, 27 Harv. Bus. Rev. 237 (1949), based on a study made for the Socony-Vacuum Company, Rodgers and Leudicke contend that price spreads for some petroleum products in the New York City area during 1947 and 1948 show that there was keen but varying (monopolistic) competition in the markets, which they would much prefer to describe as "dynamic" competition. The products chosen for study are fucl oils and unbranded gasoline, and the method that of charting price quotations.

See also testimony of M. J. Rathbone, President of the Esso Standard Oil Co., in Hearings Before Committee on Interstate and Foreign Commerce, House of Representatives, on Fuel Investigation, 80th Cong., 2d Sess. 1072 (1948).

On another, related phase of the problem, note the testimony of Henry A. Pecl, Economic Analyst, Bureau of Industrial Economics, Federal Trade Commission, Hearings Before Subcommittee of Committee on Interstate and Foreign Commerce on H.R. 107, H.R. 6047, H.J. Res. 423, 81st Cong., 2d Sess. 287 (1950) for a statement describing a world wide "basing-point" system for crude oil prices.

33. See, e.g., Standard Oil Co. v. FTC, 340 U.S. 231, 234-6 (1951); United States v. Richfield Oil Corp., 99 F. Supp. 280, 294-7 (S.D. Cal. 1951), aff'd per curiam, 72 Sup. Ct. 665 (1952); Standard Oil Co. of California v. United States, 78 F. Supp. 850, 853-6, 873-5 (S.D. Cal. 1948), aff'd, 337 U.S. 293 (1949). See Lockhart \& Sacks, The Relevance of Economic Factors in Determining Whether Exclusive Arrangements Violatc Section 3 of the Clayton Act, 65 Harv. L. Rev. 913 (1952).

34. See cases cited note 33 supra; Learned, supra note 32, at 742; DiRLAM \& KAHN, supra note 32, at 832-4; CASSADY \& Jones, op. cit. supra note 32, at 146 . See gencrally 3 Bain, The Economics of the Pacific Coast Petroinum Industky 92-110 (1947).

35. See cases cited note 33 supra and United States v. Socony-Vactum Oil Co., 310 U.S. 150 (1940); Ethyl Gasoline Corp. v. United States, 309 U.S. 436 (1940); Complaint, United States v. Standard Oil Co. of California, Civil No. 11584-C (S.D. Cal. 1950); CASSADY \& JoNES, op. cit. supra note 32, passim; Lockhart \& Sacks, supra note 33 , at $919-42$. 
pose or effect of the conduct under attack. ${ }^{30}$ The exact character of the proof that major oil companies have combined to control prices would have to wait for an actual trial, such as the pending United States $v$. Standard Oil Company of California. ${ }^{3 \pi}$

For present purposes, we shall assume, perhaps contrary to the facts as they may emerge, that in most of the different regional markets for crude oil, gasoline and other products, the requisite degree of combination among the major oil companies could be established as readily as in the Tobacco and Paramount cases. If the major oil companies can be viewed together, the problem of violation would not seem to present insuperable problems, since together they refine and sell about $80 \%$ or more of the product consumed in most market areas. Although the Columbia Stecl case properly warns against using percentages of capacity or of sales as badges of guilt, ${ }^{33}$ the market analysis of gasoline pricing required to show the major companies' concert of action would also show its price effects. The issue would then be whether the combined influence of the major companies on price, output and the entry of new firms constituted "monopolization," i.e., whether it went beyond the zone of workable competition in oligopoly markets.

The issue to which this paper is confined is integration, both as a strategic element permitting the maintenance of monopoly power, and (if the problem is indeed different) as a factor to be considered in devising an antitrust remedy. This problem will be examined on the assumption that the major companies could be found in certain market areas to have combined their market influence for the purpose or with the effect of influencing price and restricting the opportunity of competitors to enter the field.

A good deal of the recent discussion about integration under the antitrust laws misjudges the problem. Much of it is addressed to the question whether vertical integration could be or should be classed as inherently monopolistic, and therefore illegal, like effective price fixing, per se. ${ }^{30}$ Both in economics

36. See, e.g., United States v. Paramount Pictures, Inc, 70 F. Supp. 53, 71, 73 (S.D. N.Y. 1947), aff'd is part, rev'd is part on other grounds, 334 U.S. 131 (1948); United States v. Standard Oil Co., 23 F. Supp. 937, 939-40 (D. Wisc. 1938), aff'd, 310 U.S. 381 (1940); The Windsor Theater Co. v. The Walbrook Amusement Co., TRade Cases 1950-1951 If 62721 (D. Md. 1950), aff'd, 189 F.2d 797 (4th Cir. 1951).

37. Civil No. 11584-C (S.D. Cal. 1950).

38. United States v. Columbia Steel Co., 334 U.S. 495, 527-8 (1948). See Rostow, Monropoly Under the Sherman Act: Power or Purpose? 43 ILr. L. Rev. 745, 778-80 (1949); Note, Columbia Steel Case: New Light On Old Astitrust Problests, $5 S$ Yale L. J. 764 (1949).

39. Hale, Vertical Integration: Intpact of the Antitrust Laws Upon Combinations of Successive Stages of Production and Distribution, 49 CoL L. Rev. 921 (1949); Hale, Size and Shape: Individual Enterprise as a Monopoly, [1950] InL. LAw Fonuas 515, 531; Adelman, Effective Competition and the Antitrust Lares, 61 HArv. L. Rev. 1239 (1948); Adelman, Integration and Antitrust Policy, 63 Hurv. L. Rev. 27 (1949); MeLaren, Related Problems of "Requirements" Contracts and Acquisitions in Vertical Integration: Under the Antitrust Laa's, 45 ILL. L. REv. 141 (1950). For the Supreme Court's rejec- 
and in law, integration appears in many contexts, and it serves many purposes. A manufacturing company may own its own mines, or other facilities for providing its raw materials, both to assure supplies in a market where goods are sometimes short, and to obtain protection against the chance that market price will rise substantially above the expected levels reflected in the present capital cost of the facility. On the other hand, vertical integration may represent the assertion of "countervailing power," to balance the market influence of dominant suppliers. The steel mills of the Ford Motor Company and of International Harvester, and many of the procurement arrangements of Macy's, A\& $P$, and Sears, Roebuck fall into this category. If the markets for the products in question were competitive, such investments would often be socially wasteful. In the setting of actual situations of monopoly pricing, however, they probably pay society in the somewhat lower price levels their existence imposes on the rest of the market, or even in the degree of price discrimination which the exercise of "countervailing power" is able to extract from monopolistic suppliers. ${ }^{40} \mathrm{~A}$ good deal of vertical integration is integration forward, to organize distributive outlets at wholesale or retail, and thus to reach a more protected position in the market than would otherwise obtain. The ownership or contractual control of theatres by movie producers, of fabricating or processing companies by many manufacturers, and of distributive outlets by oil companies all represent integration for such purposes.

The legality of integration must be analyzed under the Sherman Act, ${ }^{41}$ we are told, like the legality of other economic dispositions: in terms of its purpose or effect, against the background of an analysis of the strategic factors in the markets affected by it. ${ }^{42}$ Manifestly, no single economic effect

tion of the per se argument see United States v. Paramount Pictures, Inc., 334 U.S. 131, 173-4 (1948) ; United States v. Columbia Steel Co., 334 U.S. 495, 519-23, rehearing denicd, 334 U.S. 862 (1948).

40. Pigou, Economics of Welfare 358 (3d ed. 1929); Lerner, The Economics or Control 55, $84-5$ (1944); Clark, Toward a Concept of Workable Competition, 30 Ax. Econ. Rev. 241 (1940) ; Galbraith, American Capitalism-The Concept of CounterVAILINg Power 115-40 (1952); Adelman, The A \& P Case: A Study In Applied Economic Theory, 63 Q.J. Econ. 238 (1949); Rowe, Price Discrimination, Competition and Confusion: Another Look at Robinson-Patman, 60 YALE L.J. 929, 949-51, 973 (1951) ; Note, 58 Y ALE L. J. 969 (1949). For a suggestive analysis of the facts in the $A \& P$ case, see Dirlam \& Kahn, Antitrust Law and the Big Buyer: Another Look at $A$ \& $P$ Case, $60 \mathrm{~J}$. Pot. Econ. 118 (1952). See also Fulda, Food Distribution in the United States, 99 U. of PA. L. Rev. 1051 (1951); Wright, Some Comments on Dr. Fulda's "Food Distribution in the United States, the Struggle between Independents and Chains," 37 VA. L. Rev. 733 (1951).

41. The problem may arise either under Section 1 or under Section 2, and the degree of power required may be different. See Rostow, Problems of Size and Integration in CCHI Syarposium, Business Practices Under the Federai ANtitrust Laws 117 (1951).

42. See, e.g., United States v. Columbia Steel Co., 334 U.S. 495, $519-27$ (1948); United States v. Paramount Pictures, Inc., 334 U.S. 131, 173-5 (1948); United States v. Aluminum Co. of America, 91 F. Supp. 333, 346 (S.D.N.Y. 1950). 
can be attributed to an industrial practice which includes, at one extreme, the ownership by steel companies of substantial parts of the national iron ore reserve, and at the other Professor Adelman's favorite illustration of a restaurant with a bakery behind, where its pies and cookies are made.43

A good many statutes have been directed against particular forms of vertical and other types of integration. The statute requiring the separation of commercial and investment banking seems dominated by a legislative purpose to eliminate situations necessarily involving conflicts of interest, often to the detriment of fiduciary obligations, although the Congress also considered that the connections of commercial and investment banks might limit competition in both fields. 14 The commodities clause of the Hepburn Act makes it unlawful for a railroad company to transport any commodity (save timber and the manufactured products thereof) in which it has a "direct or indirect" interest, except articles needed and intended for its use a common carrier." This provision is almost certainly derived from experience in the anthracite coal industry, concentrated geographically in a few Pennsylvania valleys. ${ }^{10}$ It represents the view that the coal-owning railroads of that area, by reason of their vertical integration, necessarily had monopolistic power over the price and commercial opportunities of their non-integrated rivals, and over the price at which coal was sold in New York and other consuming centers. "The purpose of the commodity clause," the Supreme Court said, "was to put an end to the injustice to the shipping public, which experience had shown to result from discriminations of various kinds, which inevitably grew up where a railroad company occupied the inconsistent positions of carrier and shipper."4t Similarly, statutory prohibitions or restrictions on combining the business of railroad and steamship, ${ }^{48}$ or railroad and trucking, ${ }^{10}$ or railroad, steamship and airline operations, ${ }^{50}$ all reflect a desire to prevent one means of transportation from limiting or controlling the growth of rival methods. The same range of ideas, in more general form, lie behind the

43. Adelman, Integration and the Outlook for the Future in CCH Srasfasiusr. BustNess Practices Under the Federal Antitzust Laws 135, 136 (1951).

44. 48 StAT. 189 (1933), 12 U.S.C. $\$ \S 377,378$ (1946). See SEN. Rep. No. 5\&4, 72d Cong., 1st Sess. $8-9$ (1932).

45. 34 Stat. 584, 585 (1905); 49 U.S.C. $\$ 1(8)$ (1946). See 40 Co:iG. REc. 6456-61, 6494-512 (1906).

46. See United States v. Reading Co., 253 U.S. 26 (1920); United States v. Reading Co., 226 U.S. 324 (1912) ; United States v. Lehigh Valley R.R., 220 U.S. 257 (1911).

47. United States v. Reading Co., 253 U.S. 26, 60-1 (1920).

48. 37 STAт. 567 (1912), 15 U.S.C. $\$ 31$ (1946) ; 37 Star. 566 (1912), 49 U.S.C. $\$ 5(14)$ (1946).

49. 49 Stat. 555 (1935), 49 U.S.C. $\$ 5(2)$ (b) (1946).

50. 52 STAT. 1001 (1938), 49 U.S.C. $\$ \$ 48 S, 4 \$ 9$ (1946). See, c.g., American Export Lines-Control-American Export Airlines, 3 C.A.B. 619 (1942); id., 4 C.A.B. 104 (1913); Railroad Control of Northeast Air Lines, 4 C.A.B. 379 (1943). Healy, Workable Compctition in Air Transportation, 35 Ass. Ecos. Rev. Supp. 229 (1945). 
interlocking directorate provisions of the Clayton Act.51 And the prohibition against combining the business of airplane manufacture and airline operations articulates the fear that commercial interest might stifle the most competitive possible growth in and improvement of airplane manufacturing, in which there is a military as well as a commercial interest..$^{52}$

In a considerable number of cases, both modern and not so modern, the courts have held the power conferred by particular forms of integration to violate the Sherman Act, as an instrument for suppressing competition. Considered broadly, defendants were held to be using economic power which they might legally possess as leverage to gain advantages which they could not otherwise have had. In economic terms, they were using the inelastic demand for one of their products or services in order to decrease the elasticity of the demand for another. As in the cases of abuse of patent, it is illegal to enlarge the area of legal monopoly by using it as a bargaining weapon in another market. The consent decree in the Swrift case, ${ }^{63}$ Justice Cardozo said, "was framed upon the theory that, even after the combination among the packers had been broken up, and the monopoly dissolved, the individual units would be so huge that the capacity to engage in other forms of business as adjuncts to the sale of meats should be taken from them altogether. . . . whether the units within the combination were acting collectively or singly." That decree required the defendant meat packers to stop selling meat at retail, and to give up selling other enumerated food products at all. In addition, they were required to liquidate their investments in public stockyard companies, cold storage plants, terminal railroads or market newspapers. ${ }^{55}$ The General Motors Corporation, which the court said had a monopoly in selling General Motors cars, ${ }^{56}$ could not employ the power implicit in that fact to restrict competition for the business of financing motor

51. 38 Stat. 732 (1914) as amended 49 Stat. 717 (1935), 15 U.S.C. $\& 19$ (a) (1946). H.R. REp. No. 627, 63rd Cong., 2d Sess., pt. 1, pp. 17-20, pt. 3, pp. 8-9 (1914). Sce Kramer, Interlocking Directorships and the Clayton Act after 35 Years, 59 Y ALE L.J. 1266 (1950).

Similar considerations of policy have been of importance in: (1) the regulation of radio; National Broadcasting Co. v. United States, 319 U.S. 190 (1943); Comment, The Impact of the F.C.C.'s Chain Broadcasting Rules, 60 YALE L. J. 78 (1951); (2) controlling the connection between television and the motion picture industry, in the prohibition against any one person controlling more than five television stations; 47 CODE FED. REGS. $\$ 3.640$ (1949); and (3) the Public Utility Holding Company Act, 49 SrAT. 817 (1935), 15 U.S.C. $\$ \S 79 \mathrm{i}, 79 \mathrm{k}$ (1946); Comment, Section 11(b) of the Holding Company Act: Fiftecn Ycars in Retrospect, 59 YALE L. J. 1088 (1950).

52. 52 Stat. 1001 (1938), 49 U.S.C. $\S \S 488,489$ (1946). Cf. Healy, Workable Competition in Air Transportation, 35 Asr. EcoN. Rev. Supr. 229 (1945); Comment, 60 Yart L. J. 1196 (1951).

53. United States v. Swift \& Co., 286 U.S. 106 (1932) ; Swift \& Co. v. United States, 276 U.S. 311 (1928).

54. United States v. Swift \& Co., 286 U.S. 106, 116 (1932).

55. Id. at 111 .

56. United States v. General Motors Corp., 121 F.2d 376, 402 (7th Cir. 1941), also "dominant position in the industry," $i d$. at 397,400 . 
car sales to dealers or to the public. While the court put the case, for reasons of pleading, on the ground that the restraint affected the commerce in cars, the decision can fairly be read to support the proposition that the crucial restraint was one in the market for financing the commerce in cars. ${ }^{.77}$ Nor could the Pullman Company use its contractual monopoly in providing pullman service in order to retain its monopoly of building pullman cars. While the court indicated that the monopoly in providing service had been intentionally and perhaps illegally maintained, an injunction against further efforts to preserve the pullman service monopoly was not regarded as a sufficient remedy, in view of the court's analysis of the offense. ${ }^{59}$ Apparently the case means that even if the Pullman Company's position as sole purveyor of the service on the railroads were entirely beyond reproach, as a monopoly position "thrust upon it" by reason of its superior skill and efficiency, it would not have been allowed to extend or enlarge its legal monopoly position by remaining in the car-manufacturing business. Or, to take another instance, the Associated Press, having become a press service of great value, though in no sense a monopoly among news services, could not be used by its members to make entry into the newspaper business more difficult and hazardous. ${ }^{\text {CO }}$

In the Reading ${ }^{61}$ and Paramonnt ${ }^{62}$ cases, the Supreme Court dealt with factual problems more nearly analogous to those of the oil industry.

In the second Reading case the Court was concerned with the legality of the common ownership, through a holding company, first of the Philadelphia \& Reading Railway Company and of its affiliated anthracite coal company, and then of their competitor, the Central Railroad Company of New Jersey and its coal company. The holding company embraced two of the six chief coal-carrying railroads-including one of the two lines serving the Schuylkill field, the largest of the three areas in Pennsylvania where anthracite is found. The Reading Coal Company held over two-thirds of the acreage, and at least half of the known reserves, of the Schuylkill field. The Central of New Jersey, a competing coal carrier, owned a considerable (but unmeasured) fraction of the coal in the Wyoming field. Together the combination included about one-third of the total annual production of the country.

In a careful opinion by Justice Clarke, the transactions were considered separately. The combination under single ownership of the Reading Railway and its coal company was held illegal, as delivering into the complete control of a single board of directors

57. Id. at 382, 399-404.

58. United States v. Pullman Co., 55 F. Supp. 985 (E.D. Pa. 1944); United States v. Pullman Co., 53 F. Supp. 908 (E.D. Pa. 1944) ; United States v. Pullman Co., 50 F. Supp. 123 (E.D. Pa. 1943).

59. United States v. Pullman Co., 53 F. Supp. 908, $908-9$ (E.D. Pa. 1944).

60. Associated Press v. United States, 326 U.S. 1 (1945).

61. United States v. Reading Co., 253 U.S. 26 (1920).

62. 334 U.S. 131 (1948). The mandate of this decision in interpreted and alplied in United States v. Paramount Pictures, Inc., 85 F. Supp. S\$1 (S.D.N.Y. 1949). 
"all of the property of much the largest single coal company operating in the Schuylkill anthracite field, and almost 1,000 miles of railway over which its coal must find its access to interstate markets. This board of directors, obviously, thus acquired power: to increase or decrease the output of coal from very extensive mines, the supply of it in the market, and the cost of it to the consumer; to increase or lower the charge for transporting such coal to market; and to regulate car supply and other shipping conveniencies, and thereby to help or hinder the operations of independent miners and shippers of coal. This constituted a combination to unduly restrain interstate commerce within the meaning of the act."

The addition of the Central of New Jersey to the Reading combination was also illegal, as conferring upon the holding company through which the combination was effected "dominating control"04 over two important competing coal companies. The combination was put together, the Court said, not by normal expansion to meet the needs of a business growing as a result of superior and enterprising management, but by deliberate, calculated purchase for control.

"That such a power, so obtained, regardless of the use made of it, constitutes a menace to and an undue restraint upon interstate commerce within the meaning of the Anti-Trust Act has been frequently held by this court."65

For this proposition Justice Clarke cites and discusses the Northern Securities case, United States v. Union Pac. R.R. Co., and International Harvestor Co. v. Missouri, relying chiefly, however, on the Union Pacific case. ${ }^{00}$

The Court majority viewed the record as showing the separate association of each railroad with its coal subsidiary, and the grouping of the four companies into a holding company. This was enough, the Court said, to bring the combination "without more" within the condemnation of the Sherman Act. ${ }^{67}$ However, the record went further. It also established the prior use of the power possessed by the combination, with that of the other anthracite railroads, in the two episodes of concerted action condemned in the earlier Reading case-the "strangling" of a project for a rival railroad by buying out one of its chief supporters at a very high price, ${ }^{88}$ and the making of long term purchase contracts with non-integrated coal companies at cuhanced prices, thereby reducing the flow of independently produced coal directly to

63. United States v. Reading Co., 253 U.S. 26, 48 (1920).

64. Id. at 57.

65. Ibid.

66. Id. at 58-9. International Harvester Co. v. State of Missouri, 234 U.S. 199 (1914);

United States v. Union Pacific R.R., 226 U.S. 61 (1912) ; Northern Securitics Co. v. United States, 193 U.S. 197 (1903). See United States v. Columbia Steel Co., 334 U.S. 495, 531 n. 27 (1948) which may raise some doubt about the present status of these cases.

67. United States v. Reading Co., 253 U.S. 26, 59 (1920).

68. Id. at 49. United States v. Reading Co., 226 U.S. 324, 351-2 (1912). 
the New York and Philadelphia markets: i.e., reducing the number of sellers of coal in those markets. ${ }^{69}$ Therefore all stock or other connections among the four companies were ordered dissolved, "for flagrant violation of the first and second sections of the Anti-Trust Act." "70

The commodities clause of the Hepburn Act was a secondary, and independent ground for the decision in the Reading case. The Court held the statute applicable, despite the Delaz'are and Hudson decision, on familiar grounds of piercing the corporate veil. ${ }^{71}$ But the primary basis for the Court's determination was its construction of the Sherman Act, without reference to the policy of the commodities clause.

In the Paranount case, eight major movie companies, of which five owned theatres, were found to have combined and conspired to control theatre admission prices, to use the bargaining power of popular films to force the sale of less popular ones and to establish unreasonable clearance and other distributive arrangements. Yet they were required not only to give up their illegal cooperation, but individually to undergo vertical divorcement. ${ }^{72}$ Theatre ownership by a major film producing and distributing company was found to be illegal, in the setting of the case. The "strategic advantages" of each company's separate vertical integration were considered important in establishing the defendants' collective power to exclude competition "when desired."73 When the strategic advantages of individual integration were "coupled" with the fact that the defendant companies separately owned $70 \%$ of the first-run theatres in the 92 largest cities of the country, and $60 \%$ of the first-run theatres in cities between 25,000 and 100,000 in population, the court concluded that the defendants violated the Act, by possessing an illegal degree of market power, and an intent to use it. Theatre ownership, as part of this complex of circumstance, was to be considered illegal "if such integration is conceived with a specific intent to control the market or creates a power to control the market which is accompanied by an intent to exercise the power." "'t Theatre ownership in the Paramount case was found to be illegal because it created an unreasonable degree of power to control the market. The court did not have to distinguish between specific and implied "intent" to achieve monopoly power, important in cases where defendants have not yet achieved an illegal degree of market power, but are charged merely with seeking it. ${ }^{75}$ "If an intent to exercise the power be thought important," Judge Augustus Hand said, "it existed in this case."70

The divorcement of theatre ownership ordered in the Paramount case, and the finding of illegality in the common ownership by the Reading Company

69. Id. at 49-50. United States v. Reading Co., 226 U.S. 324, 356-61 (1912).

70. Id. at $59-60$.

71. Id. at 60-3. United States v. Delaware \& Hudson Co., 213 U.S. 366 (1909).

72. United States v. Paramount Pictures, Inc., 85 F. Supp. 881 (S.D.N.Y. 1949).

73. Id. at 894 .

74. Id. at 893 .

75. Id. at 885 .

76. Id. at 894 . 
of an important railroad and its coal producing subsidiary, do not turn on the immediate price consequences of the integration. They rest on an analysis of the bargaining advantage which control of a necessarily monopolistic element of the market structure confers in less monopolistic market areas. The major movie companies owned a large share of the available big theatres, and operated them in a way which normally excluded independently produced films from first-run theatres, or at least severely limited their access to such theatres. Others could conceivably build their own big theatres. But under the established system they could never expect to get enough first-run films to keep them open all year around. Any other pattern of behavior would have been difficult to imagine, if the major group weighed its interests intelligently. While the court enjoined the existing system of clearances, it did not declare all clearance arrangements illegal. Contractual restrictions classifying theatres as first-, second-, or third-run would be reasonable, if reasonably restricted as to time and space, so as to constitute a reasonable way of making money from copyrighted films. ${ }^{77}$ Even the injunction against unreasonable clearance provisions, despite its scope, was not deemed a sufficient remedy to permit workably competitive entry into the business of making and exhibiting films. The preservation of limited clearance privileges in the decree made theatre divorcement inevitable, for the retention of any right to refuse first-run privileges would have made it altogether too easy for majors to block independent entry into the theatre and producing stages of the movie business. Theatre ownership by the major film companies was thus deemed illegal, under the circumstances of the market, by reason of the power it conferred to limit the potential growth of independent competitors.

Professor Spengler 78 concludes that vertical integration, unlike horizontal integration, "does not, as such, serve to reduce competition and may, if the economy is already ridden by deviations from competition, operate to intensify competition." $79 \mathrm{He}$ points out the familiar fact that where a vertically integrated firm includes one link with greater monopoly power than the others, vertical integration may serve to increase output and, where the final market is also monopolistic, to reduce market price. When embraced within unified ownership, the "bottleneck" or monopoly stage of the integrated firm is used at cost, rather than at a price enhanced by monopoly power. The economic effect would be similar if vertical integration were adopted to avoid paying a transaction tax. In such a case, the result must be that when the integrated firm sells its product to the public, in the final market, its schedule of costs would be lower than otherwise. Therefore it would react to the state of

77. Id. at 897 , and see cases note 24 supra.

78. Vertical Integration and Antitrust Policy, 58 J. PoL. Econ. 347 (1950). The article starts with an erroneous premise of law. Professor Spengler assumes that the Supreme Court is beginning to look on vertical integration as illegal por se. Exactly the contrary is the case. See note 39 supra.

79. Id. at 347. At a later point, however, he remarks that "vertical integration, as such, does not necessarily suppress competition." Id. at 351 . 
demand in that market by producing somewhat more than if it had paid a toll to monopoly at the bottleneck stage. If the market for the final product were competitive, it could profitably produce and sell more at the same price as before. If the seller had some degree of monopoly power over the price it charged in the final market, it could sell more only by lowering its price -either across the board or by way of price discrimination-and it could profitably do so by reason of the reduction in costs made possible by vertical integration.

Spengler regards the single case he examines as a general one, tending to prove that "vertical integration, if unaccompanied by a competition suppressing amount of horizontal integration and if conducive to cost and price reduction, should be looked upon with favor by a court interested in lower prices and a better allocation of resources." 80 His analysis, altogether correct as far as it goes, doesn't go nearly so far as his conclusion. It does not deal with the leverage or bargaining aspect of vertical integration essential to a full analysis of many markets, unless the qualifications of the sentence quoted above are interpreted so broadly as to deprive the conclusion of its apparent thrust. It may be preferable social policy to allow a degree of regulated monopoly profit in a true bottleneck stage of the industrial process, such as transportation, in order to achieve a wider measure of competition in the less monopolistic stages. In such cases vertical integration, while lowering the costs of the integrated producer, may simultaneously give him monopolistic advantages as the purchaser of his raw materials or the seller of his final products. Such results do not of course invariably follow on vertical integration. Each case must be examined separately to determine whether the vertical integration is a device to secure genuine cost advantages, or a mere investment, mistaken or not, or a historical accident, or an attempt to avoid paying monopoly tribute, or a move which inevitably confers monopolistic advantages at other stages of the business.

Another approach to problems of integration under the antitrust law is focussed on the fact that almost all instances of integration, except cases of pure investment, eliminate some competition in the business of the units being combined. Normally, affiliated units in related phases of the same industry deal exclusively or almost exclusively with each other. When, in the circumstances of the Columbia Steel case, United States Steel bought Consolidated Steel Corp., a small fabricating plant on the West Coast, it was taken for granted both by the government and by the defense that the purchase would eliminate the previous degree of competition both between United States Steel and other steel manufacturers in supplying Consolidated with basic steel products, and between Consolidated and various subsidiaries of United States Steel in selling fabricated products. ${ }^{81}$ Vertical integration almost invariably

-80. Id. at 352.

81. United States v. Columbia Steel Co., 334 U.S. 495, relicaring denicd, 334 C.S. 862 (1948). Comparable problems arise in United States v. Western Electric Co., CCH TRADE REG. REP. '48-'51 DeC. If 61,186 (D.N.J. 1949), attaching ounership by Ameriean 
involves removing the transactions of the integrated units from the arbitra. ment of the market. There may be some internal economies made possible by the assurance of an outlet, the elimination of selling costs, and, in some instances, through facilitating manufacturing operations. There are also often serious diseconomies, if the integrated unit turns out to produce or to distribute at higher costs than the market. And the concern assumes the full risk of obsolescence which reliance on the market would permit it to shift to others. ${ }^{82}$

The effects of vertical integration on investment and competition within an industry may take even more expensive forms. ${ }^{83}$ One or two integrated companies in an industry, may-as in steel or aluminum-control large parts of the supply of essential raw materials needed by their competitors, or, as in the earlier development of the anthracite industry, may own transportation facilities which competitors had to use to reach the market. When the dominant segments of an industry are integrated, and especially when future access to essential supplies on an open market may be in doubt, the stronger independent competitors are impelled to integrate defensively in their turn, to assure themselves raw materials, or transportation, or outlets for their products, not controlled by their rivals. The resulting market structure is likely to be one of oligopoly, at best. It is almost certain to involve a considerable volume of investment which is economically wasteful, and would never take place under circumstances of competition. ${ }^{84}$

Vertical integration-the combination under single ownership of successive stages in a particular cycle of production-is undertaken for a variety of motives, and has a variety of effects. While it generally involves some elimination of competition, since the integrated stages deal with each other rather than with the market, the significance of that fact depends upon the share of the market involved, and upon the other circumstances of particular cases. The combination of closely related processes may be required or justified for engineering reasons. Or independent elements in an organized market -like Macy's or Sears, Roebuck-may use vertical integration, through

Telephone \& Telegraph Co. of Western Electric Co., from which its subsidiarics are alleged to buy telephone equipment almost exclusively. See also, United States v. E. I. du Pont de Nemours \& Co., CCH Trade REg. ReP. '48-'51 DEc. If 61,219 (N.D. Ill. 1949). And the same approach is implicit in United States v. Yellow Cab Co., 332 U.S. 218 (1947), 338 U.S. 338 (1949), discussed in Comment, 19 U. of CHI. L. Rev. 583 (1952).

82. This phase of the problem is discussed fully by BurNs, THE DECLINE or ConPETITION C. 9 (1936).

83. See Stocking \& Watkins, Monopoly and Free Enterprise $342-4$ (1951); Muler, Unfair Cospetition c. 10 (1941) ; Burns, Tee Decline of Conpetition 41860 (1936); Edwards, Maintaining Competition 97-9, 128-30 (1949); Chamderlin, Monopolistic Conspetition 122-3 (5th ed. 1946).

84. Hale, Vertical Integration: Impact of Antitrust Lanes Upon Combinations of Successive Stages of Production and Distribution, 49 Cot. L. Rev. 921, 936-7, 949-52 (1949). 
ownership or contract, to obtain supplies of privately branded merchandise with which to undercut conventional distributors. On the other hand, vertical integration has been used in many instances as a tool of effective monopoly. It may, as in cases where ore supply is owned by a single firm, permit that firm either to dominate all subsequent stages of the manufacturing industry using the ore, or substantially to control the competitive opportunity of rivals. Or it may impose on rivals the expensive necessity of defensive vertical integration, in order to gain assured access to supply. ${ }^{85}$ Such drastic increases in the cost of entering a business may constitute a genuine barrier to the development of rival firms, and help to keep down their number. In other instances, where vertical integration includes a bottleneck stage, rivals may have to pay tribute to their vertically integrated competitor, with adverse effects on their competition. All in all, the economies and diseconomies, and the effects on competition of particular instances of vertical integration have to be examined in each case, against the background of the markets affected. In our industrial history the combination of units through vertical integration has often been an effective restraint of trade, or an instrument for achieving and keeping monopoly power.

\section{Vertical Integration in the Oil. Industry}

Does the vertical integration of the major oil companies, accomplished by virtue of their ownership of transportation facilities, and by devices for the control of price policy in wholesale and retail distribution, contribute materially to the creation and maintenance of an unreasonble degree of market power in the group of major companies, considered collectively?

The major oil companies refine and sell as their own product more than $80 \%$ of the petroleum processed in the United States. Although they produce about half of the crude petroleum extracted from the earth in this country, ${ }^{80}$

85. For example, see Stigler's analysis of vertical integration in the steel industry, Hearings Before Subcommitte on Study of Monopoly Poucr, Committce on the Judiciary, Study of Monopoly Powir, 81st Cong., 2nd Sess., Ser. 14, pt. 4A, pp. 117-40 (1950).

86. Professor Cookenboo, Structure of the Oil Industry in Brown, Reidnos o: raE Petroleusy Industry 72, 82 (Association of American Law Schools 1950), calculates that 19 major companies produced 54.1 per cent of the gross crude output of the United States in 1929, 53.3 per cent in 1933, 55.1 per cent in 1935, 51.7 per cent in 1938, 59.1 per cent in 1943, 62.0 per cent in 1945,62.4 per cent in 1947, and 63.1 per cent in 1948. Our own calculations for the years since 1948 indicate a slight decline in the share of these 19 companies, to perhaps 60 per cent on Professor Cookenboo's scale for 1950. For the years 1929-1948 Professor Cookenboo has kindly supplied a revised version of the figures used in his contribution to Professor Brown's Rendings. The nineteen companies in his sample are: Standard Oil Company (New Jersey), Socony-Vacuum Oil Company, Standard Oil Company (Indiana), Gulf Oil Company, Texas Company, Shell Oil Company, Standard Oil Company of California, Sinclair Oil Company, Cities-Service Company, Tidewater-Associated Oil Company, Sun Oil Company, Atlantic Refining Company, Union Oil Company of California, Standard Oil Company (Ohio), Phillips Petroleum Company, Pure Oil Company, Continental Oil Company, Skelly Oil Company, and Ohio Oil Company. 
they purchase a good deal of the independently produced crude oil ${ }^{87}$ at the wells, or near them. ${ }^{88}$ They own most of the pipe lines through which the largest part of crude production is gathered from scattered wells and fields, and carried to the refineries where it must be prepared for the market. ${ }^{80}$

While the pattern of location of refineries is changing, most of the growth in refining facilities since the war has taken place either in the Gulf Coast region, or in the consuming market areas, near the great concentrations of industry and population between the Chicago district and the East Coast.00

87. Although 19 majors produced only about 60 per cent of the domestic crude output in 1950 they handled over 80 per cent of all crude runs to stills. In addition some oil is typically refined by independents for the account of majors. Therefore somewhat over 80 per cent of the crude oil refined in the United States was under the direct or indirect control of 19 majors in 1950. Cookenboo, supra note 86, at 84-7. See p. 891 infra.

88. "It may be stated categorically that the producer has no markct at the refinery, and prefers to sell in the field." Wolbert, AMrerican Pipe Lines 47 (1952).

89. Wolbert, American Pipe Lines 9 (1952); Cookenboo supra note 86, at 88-90. Professor Cookenboo estimates that the 19 major companies studied in his sample carricd 84.5 per cent of all crude oil and refined products carried by major oil companies and independents in 1940. and 88.2 per cent in 1948. If the Northern and Southern groups, National Transit and Richfeld, are included, the fractions rise to 95.7 per cent in 1940 and to $96.5 \mathrm{per}$ cent for 1948. While he believes that his figures may somewhat overstate the pusition of the majors in absolute terms, there is no doubt of their approximate accuracy, and of the stable condition they reflect.

90.

Changes in Refining Capacily in the United States, 1940-1951

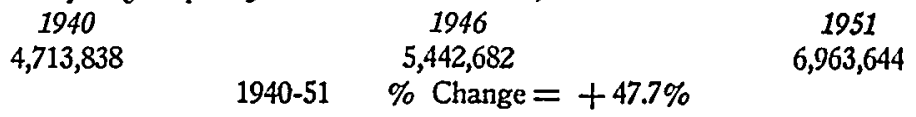

Refining Capacity in the Region from S. E. Louisiana to South East Texas*

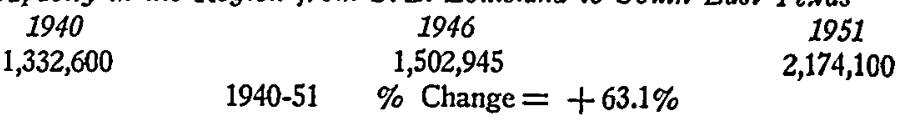

Refining Capacity in P.A.D. District III**

1940

$1,897,895$
1951

$2,484,250$

$1940-51 \quad \%$ Change $=+30.8 \%$

Refining Capacity in Chicago to New York Area*** 1940

$1,539,450$

$$
1946
$$

$1,897,000$

$\%$ Change $=+77.1 \%$

$1940-51$

Refining Capacity in Oklahoma

1940

225,875

\section{6}

219,560
1951

$2,726,350$

1951

304,500

1940-51 \% Change $=+34 \%$

* Includes S.E. La., Beaumont-Houston, Corpus Christi and East Texas.

** Includes N.M., Tex., La., Ala., Miss., Ark.

*** Includes IIl., Ind., Mich., Ohio, Pa., N.Y., N.J., Del., Md., W.Va., Ken., Tenn., Mass., R.I.

Sources: Patton, Petroleum Refining War \& Postwar 92-123 (U.S. Dep't of Comm. 1947); Petroleuns Administration for Defense, Transportation of Oll (1951). 
These are the places where it makes most sense economically to build refineries. Location near consuming areas would permit expensive and relatively permanent installations to draw their raw material from changing sources of supply, as old fields give way to new ones. And in most such areas, the price of residual oils and other jointly produced products is higher than in producing areas, or even in the Gulf Coast market. Gulf Coast refineries are economic also, both as facilities to serve the rapidly expanding consuming markets of the south and southwest, and as producing units which can reach distant markets either by sea, or increasingly, by product pipe line. ${ }^{91}$ Gulf Coast refineries have considerable elbow room, in that they can participate in foreign as well as southern and East Coast business, and may even consider penetrating the central and midwestern markets when price relations in different markets are appropriate. Their location on the Gulf Coast is rational on the assumption-altogether as reasonable as such guesses can be-that while individual fields in the south and southwest will rise and fall, a great deal of relatively cheap oil will continue to be available in Texas, Louisiana and Oklahoma for a long time to come.

The pattern of growth in refining raises a series of basic questions: Why is so much of the independently produced oil sold to the major companies? Why isn't more transported either by producers or by independent refiners to economically located non-major refineries, for independent production and distribution in the markets of the country? Is this pattern of practice inevitable? Does it reflect the results of a monopolistic market structure, or of a purpose to restrict the entry of new competitors into the industry? Is the price of crude relatively so high, and the price of gasoline relatively so low, as to make independent refining an unattractive field for investment? Is tine cost of efficient refining so high that capital requirements alone constitute an insuperable barrier to independent expansion? Is the refining business more risky than other parts of the industry, at least in the sense that the rewards can never be quite so spectacular as in oil production, whereas the pressure in years of severe price difficulty can be very real? What significance, if any, should

91. Total United States Demand and Deliveries by Product Pipe Lines, Gasoline, Kerosene and Distillate Fuel Oil-1946, 1950, est. 1952.

\begin{tabular}{|c|c|c|c|}
\hline \multicolumn{4}{|c|}{ GasoLINE } \\
\hline & Demast & \multicolumn{2}{|c|}{ Pipeline Delizeries } \\
\hline 1946 & 2139 & 490 & $22.9 \%$ \\
\hline 1950 & 2792 & 839 & $30.1 \%$ \\
\hline 1952 & 3243 & 1135 & $35 \%$ \\
\hline \multicolumn{4}{|c|}{ Kerosene \& Distillate Fuez OtLS } \\
\hline & Desnand & \multicolumn{2}{|c|}{ Pipeline Delizerics } \\
\hline 1946 & 1014 & 102 & $10.0 \%$ \\
\hline 1950 & 1445 & 238 & $16.5 \%$ \\
\hline 1952 & 1641 & 335 & $20.4 \%$ \\
\hline
\end{tabular}

(000 barrels per day)

Petroleuar Abumiststration for Defense, Transfortation of Oll 43 (1951). 
be attached to pipe line ownership by the major companies as a factor limiting the growth of existing independent refineries, and the entry of potential independent companies in this part of the business?

In the past, at least, pipe line ownership gave the major companies a powerful voice in the markets for crude. The level of pipe line rates in relation to field prices provided a distinct incentive for independent producers of crude oil to sell their oil to a major company pipe line owner in the field. Pipe line rates were so high as to discourage independent producers from transporting crude oil through the pipe lines on their own account, to be sold in markets containing more buyers than are available in any producing area. ${ }^{22}$ Similarly, the relation between crude prices and pipe line rates helped to keep independent refiners located far from particular fields from purchasing oil advantageously in those fields, and transporting it to their own account via pipe lines. This effect was enhanced by high tender requirements, and other conditions imposed on the carriage of oil by the pipe line companies. ${ }^{93}$ Although the oil and gasoline pipe lines have been common carriers in form for many years, ${ }^{04}$ they have until recently transported very little except oil or gasoline produced or purchased by other branches of their own companies. ${ }^{96}$

92. Wolbert, ANerican Pipe Lines 17-21 (1951) ; cf. Sen. Rep. No. 25, 81st Cong., 1st Sess. 19-23 (1949).

93. See, e.g., Brundred Brothers v. Prairie Pipe Line Co., 68 I.C.C. 458, 462-4, 465-6 (1922) (minimum tender requirements of 100,000 barrels ordered lowered to 10,000 barrels); Reduced Pipe Lines Rates and Gathering Charges, 243 I.C.C. 115, $133-7$ (1940) (minimum tender requirements varying from 500 to 100,000 barrels-respondents ordercd to show cause why 10,000 barrels would be unreasonable) ; Petroleum Rail Shippers Assn. v. Alton \& Southern R.R., 243 I.C.C. 589, 655-8 (1941) (25,000 barrels fixed as reasonable minimum tender for products pipe line); Reduced Pipe Lines Rates and Gathering Charges, 272 I.C.C. $375,382-3$ (1948) (7 pipe lines ordered to lower tender requirements of 100,000 and 25,000 barrels to conform with ICC tender requirements).

For summary of the cases and an analysis of the problems see WoLdert, AMERICAN PIPE LiNes 22-41 (1952); Comment, 51 Yare L. J. 1338, 1343-6 (1942).

94. 34 STAT. 584 (1906), as amended 49 U.S.C. $\$ 1$ (1946). Attempts by majors to avoid jurisdiction under the act were thwarted in In the Matter of Pipe Lines, 24 I.C.C. 1 (1912) and the lines were ordered to file tariffs, $i d$. at 11 . When the lines challenged Commission orders as a deprivation of property without due process of law, the Supreme Court found them to be common carriers in substance, The Pipe Line Cases, 234 U.S. 548 (1914), and ordered compliance, excepting from the order one line that carricd only its own oil from "its own wells to refinery." Id. at 562. This exception was qualified in Valvoline Oil Co. v. United States, 308 U.S. 141 (1939) (ICC jurisdiction challenged by Valvoline because its line only carried oil to Valvoline's own refineries; held, since the oil was purchased "from many sources" the exception does not apply) and further diminished in Champlin Refining Co. v. United States, 329 U.S. 29 (1946) (where Champlin's products pipe line carried output of Champlin's refinery to market F.O.B. refinery, pipe line is within jurisdiction of Hepburn Act). Note also United States v. Champlin Refining Co., 341 U.S. 290 (1951) (abandonment by Champlin of F.O.B. pricing docs not change status, but since services "unsought after" by independents, Champlin's rates could not yet be regulated even though company must comply with Uniform System of Accounts). For summary, consuit Wolbert, AMERICAN PIPE LiNes 117-132 (1952).

95. Reduced Pipe Line Rates and Gathering Charges, 243 I.C.C. 115, $121-2$ (1940). 
In A National Policy for the Oil Industry, a review of efforts to control pipe line rates, both by administrative regulation under the Interstate Commerce Act and by the consent decree under the Elkins Act in the Atlantic Refining case, ${ }^{96}$ reached the conclusion that the rate control approach had little to offer as a means of enlarging the area of competition in the oil industry. At any level of profits likely to be sanctioned by the Interstate Commerce Commission as a reasonable return on an assumed value, shippers would be forced to pay their competitors a profit on the transport service, which would constitute a rebate affecting competition among the oil companies. On the other hand, it was contended, a reduction of rates that would approach economic norms would be a step of limited, but nonetheless considerable promise.

"For even if the independent seller reached across all the hurdles to a somewhat larger market, he would find his position had not been radically improved. He would confront a larger group of possible buyers of his product, but it would still be a small group of buyers, compared with the greatly increased number of sellers who would simultaneously have come with him from the separate oil fields to the common market place. The difference, however, though not revolutionary, might well prove significant. If the independent producers of crude could use the pipe lines on equal terms as shippers, they could more easily do business with independent refiners. The dominance of the major companies as buyers in the crude markets would perhaps be qualified. Thus the monopoly control factors which have steadily cut the independent refiners' share of the market for the last twenty years would be partly ameliorated, and the independent refiners would have gained a less restricted opportunity to compete with the major refiners. They would have greater access to sources of supply, and would therefore be less completely under major company control.",gr

Professor Wolbert, in a thorough, careful, and on the whole critical study of the monopolistic consequences of major company pipe line ovnership in the oil industry, ${ }^{28}$ agrees with this analysis, as a view of past experience.

96. United States v. Atlantic Ref. Co., 10 U.S.L. WEEK 2403 (D.Col. 1941).

97. Rostow, op. cit. supra note 1, at 63-4.

98. Wolbert, Arrerican PIPe Lines (1952). The next few pages of this paper will be in part a review of, and a comment upon Professor Wolbert's conscientious work: It is an analysis of the issues behind the demand for vertical disintegration in the oil industry, which, he says, have in recent years "swelled, roared, and sullenly subsided, only to rise again like the crest of an angry sea." Id. at 3. He considers the history and main elements of the controversy, and the two major remedies so far employed, regulation by the ICC and the consent decree in the Atlantic Refining Company case. The book is carefully prepared and documented, and generally well-informed about industry conditions, although its treatment of the problems encountered under the consent decree is rather more abstract than necessary. Consultations could have produced the 
But he contends that ICC regulation, if reformed and made more vigilant and continuous, should be sufficiently effective to eliminate the monopolistic leverage previously implicit in the major company pipe line ownership. ${ }^{20}$

"The basic fact is that until pipe line tariffs provide for 'cost rates,' or the lines are completely divorced, the shipper-owners will realize some competitive advantage over outside shippers to the extent of the difference between the cost and the rate. The reason for this is that shipper-owners necessarily ship at cost, whether the line is operated as a department of the corporate shipper, as a wholly-owned stubsidiary, or as a joint adventure, while outside shippers must pay the tariff rate. In addition to this differential, shipper-owners obtain a further advantage by realizing a profit for carrying their competitors' goods. During the early formulative period of petroleum industry development, the tremendous competitive differential in the transportation phase enabled the large companies possessing extensive pipe line systems to locate their refineries near tidewater or large marketing areas, while the smaller outfits were forced to construct their plants near the producing fields.

"The monopolistic potential created by an extreme spread between pipe line costs and tariff rates was brought to the attention of the Interstate Commerce Commission during the hearings in the Reduced Pipc Line Rates case. The cost-rate differential was discussed at several points during the TNEC Hearings. The members of the Committee from the Department of Justice and the Federal Trade Commission felt that payment by the carrier to the shipper-owner of any part of the difference between cost and tariff rate constituted a rebate (on shipper-owner movements) or a draw-back (on outside shipments). Industry's spokesmen agreed that exorbitant rates created an unfair advantage but insisted that a reasonable rate would not create an unfair advantage because the independent shipper would be availing himself of the benefits of the shipper-owner's capital to do more business on less capital than he could have done if he had constructed his own line."100

Apparently Wolbert concludes that while administrative regulation of pipe line rates and other practices by the ICC is moving on sound lines, it requires further development to be fully adequate: $: 101$ increased staff and funds, reliance principally on investigation by the Commission rather than on shipper complaints, and the creation within the Commission of a special Bureau

answers to many of the questions posed. A few minor errors may be noted. The 10 per cent-90 per cent rule used in computing the division of joint rates is incorrectly stated. Id. at 22 n. 102. There have been more independent lines than Crusader and Prairie. Id. at 102. Buckeye is perhaps the most important.

99. Wolbert, American Pipe Lines 163, 155, 141-2 (1952).

100. Id. at 52-3.

101. Id. at $141-2$. 
charged with primary responsibility in pipe line matters. Given these changes, he believes, divorcement of the pipe lines from the major companies would be unnecessary; ${ }^{102}$ the monopolistic advantages of pipe line ownership would be eliminated by rate regulation. Rates which correspond to costs could not give the carrier-oil company a competitive advantage. Although the analysis is correct, it should be emphasized that while "costs" for this purpose should include a normative long-run return on capital, "cost rates," in Wolbert's sense of the term, by no means correspond to the rates which normally pass muster in the process of utility regulation as providing " $\mathrm{a}$ fair return on fair value." Assuming the achievement of effective rate regulation in this special sense, he would dismiss the Atlantic Refining Connsany proceeding, limiting to $7 \%$ on the ICC property valuation the dividends which any pipe line company can pay to its parent major oil company. ${ }^{103}$ This position may not fully represent Wolbert's final conclusions on the pipe line question. He would also have the government undertake regional antitrust suits against the major companies operating in any market "to prevent abusive restraints of trade or any undue use of leverage made possible by large aggregations of economic power."10:

Discriminations in service, refusals of service, and some older methods for forcing the sale of crude to major companies in the field seem largely to have disappeared - or at least greatly diminished-in pipe line administration.

But the competitive significance of present day rate levels, and of the rate structure, is by no means so obvious as Wolbert implies. Rate regulation is incapable, as a matter of practical experience, of achieving so precise a result as rates which would at any moment of time yield no more than a fair return on a fair value. And it is a fortiori incapable of achieving "cost rates," as Wolbert uses the phrase. Because a large fraction of pipe line costs are fixed, ${ }^{105}$ profit varies greatly with volume. ${ }^{100}$ Operating and other expenses fluctuate more than rates, and the replacement cost of capital equipment has probably outstripped depreciation reserves during the last decade of sustained

102. Id. at $104,163-4$.

103. Id. at 163 .

104. Id. at 107-8, 163-4.

105. For the year 1950, depreciation, maintenance and general office expenses were $\$ 98,699,820$, or 50 per cent of total expenses of $\$ 194,829,712$ for the trunk lines of 77 companies reporting to the ICC. Depreciation, maintenance and general office expenses totaled $\$ 29,160,106$ of $\$ 59,871,75 \%$ in gathering lines of the same companies in 1950 . ICC, Statistics of Oil Pipe Line Coarpanies for 1950 24-5 (1951).

106. Of course volume is not the only factor which would determine the profitability of pipelines if they carried the oil of outside shippers. Wages and material costs, taxes, and rates are all variables entering the equation. The increasing shares of the transport business done by product pige lines, as well as some rate increases, may accuunt for recent increases in profits. See ICC, 64tr Annual Refort 16 (1950). For further relevant statistics see ICC, Statistics of Oil Pipe Line Coarpanies fos 1950 (1951). See generally Reduced Pipe Line Rates and Gathering Charges, 272 I.C.C. 375,378 (1948). 
inflation-a circumstance hardly likely to diminish in significance in the forseeable future. Whether at any period regulated utilities earn more than competitive industries, and thus enjoy monopoly profits, or less, and therefore starve for capital, depends on a combination of circumstances: the relative changes of wages and material costs, on the one hand, and of rates and volume on the other. How to control utility rates in a rapidly changing (and somewhat inflationary) economy presents one of the most baffling general problems of public policy. It could hardly be expected that pipe line regulation under the Transportation Act, considerably less rigid than the regulation of rail rates or the usual forms of state gas and electric utility regulation, ${ }^{107}$ would be able through time to eliminate the competitive advantages which major oil companies possess by virtue of pipe line ownership.

Nonetheless, the important problem is that of more or less. For a variety of reasons, pipe line rates are relatively lower than they used to be. ${ }^{108}$ Despite rate changes, they probably still constitute a disadvantage, at most stages of the trade cycle, added to the others which face a company seeking to enter the refining stage of the industry. Is that disadvantage sufficiently material to justify or to require divorcement? Like many another market force, has it been repealed by inflation?

107. 34 STAT. 584 (1906), as amended, 49 U.S.C. \& 1 et seq. (1946). The most significant hiatus in pipe line regulation lies in the exception to ICC jurisdiction carved out in The Pipe Line Cases, 234 U.S. 548 (1914), for lines carrying their own product from their own wells to their own refineries. See note 94 supra. Although this exception has been narowed to require all interstate pipe lines to file accounts and data with the ICC, United States v. Champlin Refining Co., 341 U.S. 290 (1951), it still lenves carriers within its scope free from rate regulation power of the ICC, at least until outside shippers seek (or perhaps need) to use the line. Id. at 297-8.

Moreover, unlike rail and motor carrier regulation, pipe line regulation does not seern yet to have taken into account such significant factors as interpipe line competition and "value-of-the-service" to shipper-another way of measuring economic conditions. Compare Reduced Pipe Line Rates and Gathering Charges, 243 I.C.C. 115, 143.4 (1940) (pipe lines), with Petroleum Rail Shippers Assn. v. Alton \& So.R.R., 243 I.C.C. 589, 639 (1941) (pipe lines and railroads), and with Petroleum Products from Wyoming to Montana, 276 I.C.C. 720 (1950) (railroads and motor carriers).

It is not necessary for the purposes of this paper to get into the controversy among economists about appropriate standards of rate making for utilities, and especially the so-called "marginal-cost-pricing" issue-see Hotelling, The Gencral Welfare in Relation to Problems of Taxation and of Railway and Utility Rates, 6 Economerrics 242 (1938); Littie, A Crittque of Welfare Economics (1950), except to note (1) that marginal cost is not even theoretically an appropriate standard for rate-making at any particular short-run level of output, since under competitive conditions output is determined by the relation of marginal cost to price, not price by marginal cost. Rostow, op. cit. supra note 1, at 49; and (2) that an appropriate cost standard for pricing the product or service of a regulated utility would depend on the scale of output achieved, which might in turn depend on the price charged. In short, the problem is probably insoluble theoretically, and can only be dealt with by trial and error.

108. See note 5 supra. 
Recent Growth of Independent Refining.

The oil industry has been expanding rapidly. The total consumption of oil for all purposes in the United States has risen from about 4 million barrels a day in $1940^{109}$ to 6.8 million barrels daily in 1950 and about 7.3 million barrels a day in $1951 . .^{110}$ The growth in petrochemicals has been phenomenal, and has been shared by some of the newer strong companies in the field, notably Lion Oil Company. In many industries, periods of sustained expansion seem to result in the relatively greater advance of smaller than of larger companies, both in rates of profit and in rates of growth in asset values. ${ }^{111}$ In such periods smaller companies, and even new companies, seem to enjoy an advantage over established market leaders, if-and the qualification is vital-increased demand is allowed to force prices up enough to encourage the entry of new firms into the industry. It would take a full analysis of the sociology as well as the economics of industry to account satisfactorily for all the elements which make up this process. It is a reasonably well documented fact, however, which should be prayerfully considered by the responsible management of big business as the possible basis for a new approach to its problems of effective organization in the interests of profit maximization. The economic prospect of continued high levels of employment and growth, sustained not only by the Cold War, but by the fiscal and monetary policies of government, presents an urgent challenge to those who direct our larger corporations-a challenge which so far seems not to have been fully considered, nor indeed squarely faced.

Dr. Joseph E. Pogue and Frederick G. Coqueron have recently measured the growth of a group of thirty oil companies. ${ }^{112}$ Their sample is a representative one, including both the large integrated companies, certain substantial companies engaged principally in land holding and production, and some smaller producing and refining companies. They have compiled financial data on the operating results achieved by this group since 1934, and have compared results for three classes of companies within their sample: 13 com-

109. Department of the Interior, Oil and Gas Division, quoted in Hcarings Before Subcommittee of Committee on Interstate and Foreign Comsmerce on H.R. 107, H.R. 6047, H.J. Res. 423, S1st Cong., 2d Sess. 29 (1950).

110. Petroletsi Adarinistration for Defense, Trastspartation of Oll 3 (1951).

111. See materials cited and discussed in Rostow, $A$ Reply, $57 \mathrm{~J}$. PoL. Econ. C0, 64-5 (1949) ; Adelman, The Measurentent of Industrial Conecniration, 33 Rev. Econ. \& STAT. 269, 278-85 (1951). See also, Lintner \& Butters, Effect of Mergers on Indisstrial Concentrations, 32 Rev. Econ. \& StAT. 30 (1950).

112. Sources: 1940 and 1947 figures, Pogue, The Function of "Profits" in the Petroleusir Industry 20 (1948); 1950 figures, 1fCopy's Industands (1951). There may be some slight, though we believe harmless, deviation in content between $\mathrm{Dr}$. Pogue's figures and those for 1950. For 1950, Borrowed and Invested Capital includes all longterm debt and capital accounts not including "reserve" items; Tatal Assets is the balaneing figure; and Net Operating Income is taken "after taxes." The sample used is discussed at length in Pogue \& Cocoueron, Financlal Axalysis of Thinty OIL Cosspanies (1945 and 1950). One source of difference between the figures is that in order to preserve 


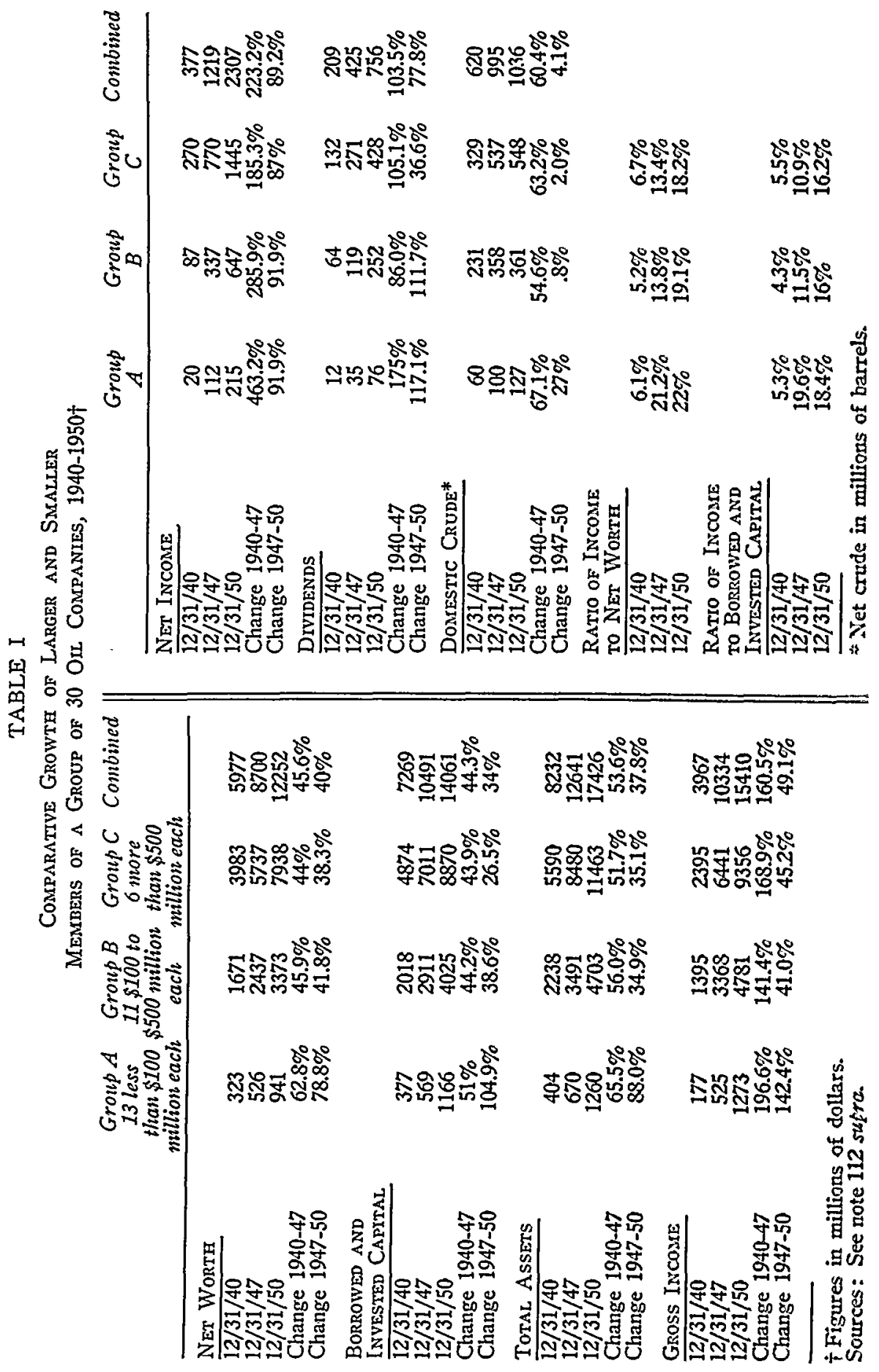


panies whose net worth on December 31, 1947 was less than $\$ 100$ million (Group A), 11 companies whose net worth on that date was between $\$ 100$ million and $\$ 500$ million (Group B), and 6 companies whose net worth was over $\$ 500$ million (Group $C$ ). We have brought their figures through 1950 , on what we believe to be a comparable basis, although they are not to be considered responsible for our calculations. These figures, together, with two computations of "profit" rates, are included in Table I.

For purposes of the problem of integration, the nature of the sample may give too much weight to production, and its relative profitability under prevailing circumstances of taxation, ${ }^{113}$ production controls, and especially priceposting methods. Moreover, debt financing is most significant in the pipeline branch of the industry, so that the ratio of net income to net worth for integrated companies would show some leverage not available for companies with little debt.

With these qualifications, the tabulation shows that the smaller members of the group have grown more rapidly than the larger ones, by most criteria. While the larger companies were more profitable in 1940, a year of less than full employment, Group A was distinctly more profitable both in 1947 and in 1950. Thus the 13 smallest companies in Group $A$ increased their net worth $62.8 \%$ between 1940 and 1947, and 78.8\% between 1947 and 1950, as compared with increases of $44 \%$ for the 6 companies in Group C, between 1940 and 1947, and of $38.3 \%$ between 1947 and 1950. The net income of the companies in Group A increased by $463.2 \%$ between 1940 and 1947, while that of companies in Group C rose 185.3\%. Between 1947 and 1950, the net income of Group A rose $91.9 \%$, while that of Group $C$ rose $87 \%$.

On the other hand, a separate examination of the refining phase of the industry reveals that new refinery operations and companies which had a refining capacity of less than 50,000 barrels a day in 1946 have grown less than companies which in 1946 had a capacity above that figure.

Companies which in 1946 had a capacity of more than 50,000 barrels a day had $74.1 \%$ of capacity in $1940,75.6 \%$ in 1946 , and $78.8 \%$ in 1951, whereas companies which had less than 50,000 barrels a day capacity in 1946 had $25.9 \%$ of capacity in $1940,24.4 \%$ in 1946 and $21.2 \%$ in 1951 . As is

continuity for the 1950 calculations we have substituted Sunray Oil Co. for Barnsdall, whereas Pogue and Coqueron replaced Barnsdall with Cities-Service.

The following companies are included in the sample studied by Pocuz \& Cogurson:

A. SMALL 13-*Amerada, *Houston Oil, *Louisiana Land, Lion Oil Ref., ${ }^{\text {XIid- }}$ Continent, *Pacific Western, Plymouth, Richfield, *Seaboard of Del., Skelly, Texas Gulf, *Texas Pacific, Sunray.

B. MEDIUMI 11-Atlantic, Continental, Ohio Oil, Phillips, Pure, Shell, Sinclair, Standard Ohio, Sun Oil, Tidewater, Union Oil.

C. LARGEST 6-Gulf, Socony, Stnd/Cal., Stnd/Ind., Stnd/N.J., Texas Co.

* Primary producing company, or substantially interested in non-oil operations.

113. See Baker \& Griswold, Percentage Depletion-A Correspondence, 64 Hasw. L REV. 361 (1951). 
TABLE II

Crude Oil Refining Capacity, Conpanies with MORE OR LESS THAN 50,000 BARRELS/DAY CAPACITY IN 1946.

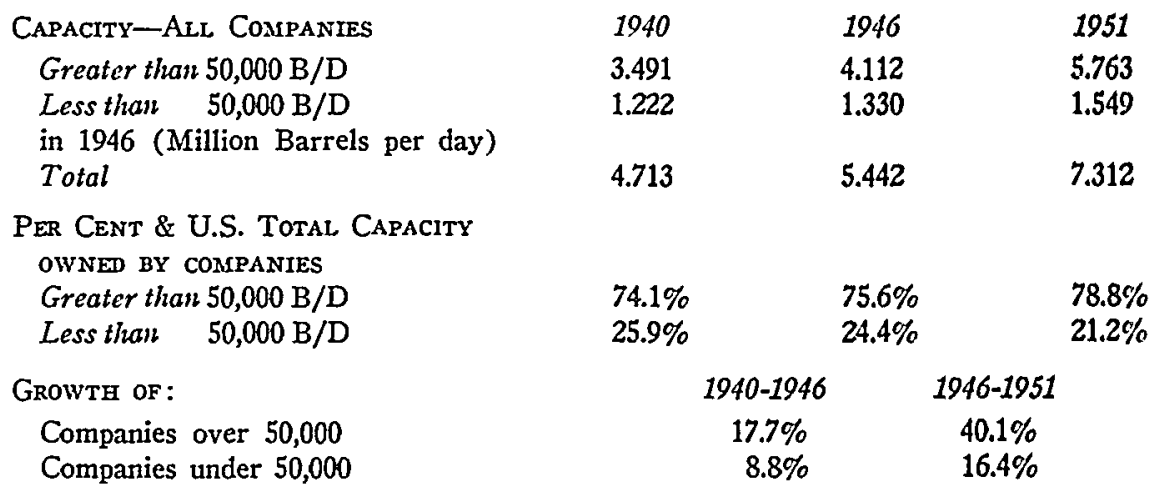

Sources: 1940 and 1946 figures are from Patton, Petroleum Refining War ANd PostWar (U.S. Dep't of Comm. 1947); 1951 figures are from the Oil and Gas Journal, March 17, 1952, p. 321 et seq. and include only operating refineries.

implicit in this result, the larger companies increased their capacity $65 \%$ between 1940 and 1951, whereas the capacity of the smaller ones increased only $26.6 \%$. Most (perhaps all) independent refiners had less than 50,000 barrels a day refining capacity in 1946.

While refineries exist for different markets and different products, so that optimum size may vary according to circumstance, it is apparent that the trend revealed in Table II can hardly be attributed to technological imperatives based on economies of scale. Several independent refiners have stated in their replies to questionnaires that in their experience the minimum efficient scale of refining is currently between 5,000 and 12,000 barrels per day capacity. One such response, based on engineering estimates, is that a well located Mid-Continent refinery, using catalytic cracking, could be altogether efficient at a capacity of 15,000 barrels a day, and would cost approximately $\$ 15,000,000$. Another places the minimum efficient size of a competitive refinery in his district at 17,500 barrels a day capacity. Dr. Robert $\mathrm{E}$. Wilson, Chairman of the Board of Standard Oil Company (Indiana) has recently said that a diversified products refinery of 30,000 barrels a day capacity is large enough to be reasonably efficient, although "maximum efficiency and minimum costs require throughputs several times this," with the result that several refineries have been built up to handle over 200,000 barrels a daya small fraction of the total current national capacity of about $7,000,000$ barrels a day. ${ }^{114}$ In considering the problem of entry into the refining business, it is significant too that the process of increasing technological specialization in the industry has resulted in the construction of refineries becoming

114. Wilson, Is Big Business Badq-Fact v. Fiction 3 (reprint of specch bcfore Antitrust Symposium of Chicago and Illinois Bar Associations, Chicago, Ill., Jan. 18, 1952). 
almost entirely a matter for engineering firms, whose services are available on contract to all comers. While the staff of the refining company normally oversees the construction job, even the largest major companies no longer build refineries themselves.

A study of refining trends made by Professor Leslie Cookenboo indicates that a group of 19 companies, which refined $79 \%$ of all runs to stills in 1930, and $81.2 \%$ of such runs in 1937 , had risen to $82.5 \%$ in 1948. Our own estimates indicate that this percentage, calculated on what we believe to be the same basis, rose to $82.9 \%$ in 1949 and $83.1 \%$ in 1950.110

In the absence of any recent full-scale enquiries into over-all changes in the oil industry, it is not easy to document the relative growth of large and small oil companies in detail, or to trace the fate of new entrants into the field, or of radically expanded older independents. Nonetheless, if one may rely on impressions, backed by interviews and consultations, and a questionnaire circulated to 64 smaller refining companies, ${ }^{110}$ this seems to be what has happened since the war: several relatively strong companies have emerged, or gained so rapidly in strength as to constitute market factors of new significance, although very few have grown as much as the average rate of increase in capacity for the industry as a whole. Each of the refining companies has had to gain competitive and assured access to crude oil, and the companies engaged exclusively in the distribution of products have had to arrange for regular supplies of gasoline. In at least one instance-that of the Ashland Oil \& Refining Company, operating principally in Kentuchy, Indiana, Ohio, Pennsylvania and West Virginia-reliance has been placed on its own greatly improved barge line operations. A considerable number of the expanded newer companies operate in or near the Gulf Coast. Their transportation problem is less acute than in the case of refineries located in the northeast or middlewest, although they may have to pay a transportation premium of some importance, as compared with their major company competitors. Several independent companies depend on their own tankers for transportation from the Gulf Coast to East Coast points. In the Chicago area, which is served by five crude oil pipe lines, as well as several product lines, at least

115. Cookenboo, supra note 86 , at $\$ 2$, as revised by his subsequent calculations. 1949 and 1950 figures from MOODY's INDUSTRIALS.

Of a group of five independent refining companies, Ashland Oil \& Ref. Co., Casden Petroleum Corp., Deep Rock Oil Corp., Leonard Refineries, Inc., and Lion Oil Co., only Ashland increased its refining capacity substantially between 1940 and 1950, and only Ashland and Lion made conspicuous gains in net worth and net income. Moody's Industnsus, 1941, $1942,1947,1951$. The special problems presented by the growth of refineries owned by cooperatives, favored both by legislation and by forces of public opinion (and therefore of company policy in relation to opinion) constitute a variation. See MAtress, Penroueuss Operations of Fararer Cooperatives (U.S. Dep't Agric, Farm Credit Administration, 1951).

116. Listed in PAtron, op. cit. supra note 90, and Oil and Gas Journal, March 17, 1952, p. 321 et seq. 
one well-managed independent refining company (Globe Oil \& Refining Company), producing a substantial volume of products, has been able to rely on common carrier transportation, and to grow considerably.

The responses to questionnaires varied, certain companies indicating that dependence on outside pipe lines was a handicap, both in cost and in service, others (uniformly in areas where the distance of carriage was short) reporting that the use of major company pipe lines was not a disadvantage.

In general, it appears to be true that, although incentives and opportunities for growth and entry are nearly universal, independent refining has advanced most where it is not dependent on transportation facilities owned by major companies for substantial hauls. Even in the Gulf Coast area, where certain companies have expanded on crude supplied by major companies, they have encountered market situations which confirmed their dependence on their suppliers, prevailing within the pattern of price leadership. Episodes of this kind, against the background of the historic memories of the industry, have accentuated in many cases the urge of the newer company to integrate in its turn, so as to gain independent access to sufficient supplies of crude, and often also to have at least partial direct outlets for the final sale of its products. On the other hand, where transportation is available on equal terms, independent refining in market areas seems to develop rapidly. Thus a new, small independent refiner, International Refineries, Inc., has undertaken to build a 10,000 barrel a day installation in Carlton County, Minnesota, depending on supplies from Canada via a subsidiary of the Interprovincial pipe line, a common carrier line financed both by some major companies and by outside capital. 117

On the basis of a tentative and preliminary enquiry into the growth of independent refining companies, the general pattern of movement within the industry seems to justify these conclusions:

(1) In a period of sustained expansion, approximately at the rate of the overall expansion of industrial output, some few smaller companies, especially those engaged in oil production, have grown faster than the average. But the percentage of oil produced by the major companies has risen from about $52 \%-55 \%$ in the pre-war period, to something over $62 \%$ in the war and immediate post-war period, and is now about $60 \%$. Meanwhile the percentage of refining done by the major companies has increased somewhat in recent years, and is now higher than ever before.

(2) Most of the independent refining companies which have made spectacular gains have done so without extensive, long-distance use of majorcompany owned pipe lines. In the main, they have solved their transport problem by owning tankers, importing oil from Mexico, or by developing efficient, low-cost barges. In several instances, their capacity to grow seems to have

117. Prospectus, International Refineries, Inc., Sept. 24, 1951, pp. 5-6. The estimated cost of the 10,000 barrel a day combination unit, embodying a fluid catalytic cracking process, is $\$ 6,700,000$. Id. at 6 . 
been based on a purchase of government war surplus property-either a refinery or a tanker, or both.

(3) Despite some increase in the outside use of pipe lines as common carriers, ${ }^{118}$ and the efforts of some pipe line companies to develop such business, the bulk of independently produced crude is still sold to major companies in the field, for transportation to their refineries for processing and distribution.

In short, in the case of the oil industry the beginning of analysis from the point of view of the antitrust laws is the proposition that the major companies are oligopsonists in the crude purchasing market and oligopolists in the sale of refined products. ${ }^{119}$ This is by no means a final answer to the antitrust problems of the oil industry. The courts must determine whether the system of monopolistic competition in buying and selling satisfies criteria of workable or effective competition. The answer may conceivably be different in different local markets. In a few markets, entry has proved relatively so easy, particularly through newer types of large-volume filling stations, as to generate frequent price "wars."120 The line between effective and ineffective competition isn't easy to draw, a priori. It would require an evaluation of price formation, entry into the industry, the level of costs and other relevant factors. Ragged and unstable monopolistic competition shades into workable competition at a point which must be ascertained in the particular case. The problem of judgment, however, is not markedly difficult in most

118. Wolbert, AMrerican PIPE LINEs 45 (1952). The factual validity of the proposition that most pipe lines carry mainly goods in effect ovned by the carrier should be reexamined. It seems likely that in many areas material owned by a major company moves not only through its own lines, but through several other connecting lines, owned by other major companies, in order to reach its final destination. Where each major holds an ownership interest in the pipe line in proportion to its share of the traffic, the issue is unchanged. But to the extent that such movements are handled in fact by payment of the full tariff, and division of joint rates, the entire problem is altered.

119. Id. at 99.

120. See, e.g., Dirlam \& Kahn, supra note 32 at \$32-4; cf. Brows, גIULVHIL, Trossp-

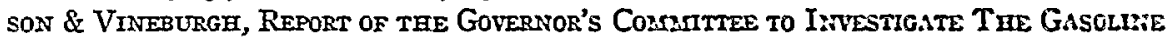
PRTCE WAR (Conn. 1950). The report discussed the normal price cutting of private brands and went on to state: "More drastic in its effect was the opening in July by the Saveway chain, of a large 'super service station' in East Hartford. This company builds only very large stations, buys its gasoline in bulk for storage in tremendous tanks at the station and offers only limited services-that is, motorists are expected to perform such free services as air and windshield wiping for themselves. The Saveway station started out selling 3 cents or 4 cents below the general retail price, and its volume of sales soon had a marlied effect on all stations in the area. ... [I]ts volume... . soon reached several hundred thousand gallons per month. Since the average station sells only 10,000 to 20,000 gallons per month, it will readily be seen that the impact of the Saveway station was considerable.

"The quick response of prices generally to the challenge of Saveway was initiated by the Sun Oil Company. Sun, far from denying its intention to meet the competition of Saveway and other large-scale cut price operators, has defended itself publicly. . . . Sun's position is that it will encourage its dealers to reduce prices to whatever extent necessary to recover gallonage lost to private-brand competition." Id. at 6-7. 
petroleum markets. The pattern of price formation, the significance of advertising and other selling costs, and the difficulties of entry into the refining phases of the business constitute what would generally be regarded as a clear-cut example of organized and socially expensive oligopoly-well beyond the limits of workable or effective competition.

If used alone, a comparison of profit rates is an inconclusive approach to the problem of distinguishing effective from ineffective competitive oligopoly. In the first place, as Judge Learned Hand pointed out in the Alcoa case, "it is no excuse for 'monopolizing' a market that the monopoly had not been used to extract from the consumer more than a 'fair' profit. The Act has wider purposes." ${ }^{21}$ Especially in recent periods of expansion, many industries in which sellers have considerable power over price have not raised their prices as much as prices have been driven up by demand in more competitive sectors of the economy. It is an extraordinarily dangerous long-run policy, which may have socially damaging effects on the allocation of available capital among industries. Many motives may account for this phenomenon. As Professor Bain suggests, such policies may be rational for monopolists, in that they keep price enough below the theoretical maximum "to forestall entry and thus to maximize the long-run profits of the established firms." 122 In the second place, concentration on comparative profit rates, while interesting and suggestive, must be supplemented by a full consideration of the level of costs. Many cases of oligopoly involve serious waste-uneconomic expenditure designed to influence demand or to multiply distributive facilities. A low profit rate above excessive costs may be socially worse than a high profit rate above minimal costs. Thirdly, the comparative level of profit as such has no particular significance of itself. The level of profit must be evaluated in relation to the state of the trade cycle, and the development and structure of the industry. In an expanding competitive industry, profits should be high precisely in order to attract new firms and new capital. Under competitive conditions, price would never be close to cost at any particular time. Differences between prices and costs are the main mechanism of competition for guiding resources to their most productive possible use.

If it is assumed that the industry's pricing practices fall on the monopolistic side of the boundary line-an issue we do not propose to re-examine herewhat bearing if any does major company ownership of the pipe lines have on prices and entry? Would the major companies remain effective "oligopsonists" in the crude market if they did not own the pipe lines? Would entry into the refining stage of the business be appreciably altered by separation of the pipe lines from major company ownership?

121. United States v. Aluminum Co. of America, 148 F.2d 416, 427 (2d Cir. 1945). Sce also note 22 supra.

122. Bain, Relation of Profit Rate to Industry Concentration, 65 Q. J. EcoN، 293, 294 n. 7 (1951). 
Wolbert contends that while pipe line rates in the past discouraged outside use of the pipe lines, and made it advantageous for producers to sell their crude to major company purchasers, this result would probably have occurred anyway. ${ }^{123}$ Independent refiners located in large consuming areas could not have used the lines, he believes, because pipe line shipment involves a timelag and a tie-up of capital in financing the movement of crude during that period; because of the possibility of contamination, if they wished crude of higher gravity then the common flow of oil transported in the line; and because of the complications of bookkeeping involved in paying divisional interests.

These are hardly substantial arguments. Independent producers located in large consuming areas have tied up a great deal of capital in their own barge lines or tankers, and have accepted even longer periods of delay, as a consequence of their use of such means of transportation. The use of commonstream as compared with segregated shipment hardly presents a major problem, under current minimum tender practices and current techniques of pipe line operation. And modes of payment to divisional interests is an issue of bookkeeping which could hardly hold back a refiner determined to try his chances in a business requiring a good many million dollars of capital. In addition Wolbert notes that existing lines often do not reach the exact location of an independent company's refinery, having been built to serve major company installations in the area. ${ }^{124}$ The point is not conclusive. A short connecting line is not beyond the reach of a strong independent refinery, ${ }^{125}$ nor beyond the initiative of an independent pipe line company interested in the business of regularly transporting oil to the independent refiner. Naturally, a major company pipe line owner would have no strong interest in providing such a facility. It doesn't follow, however, that an independent pipe line company would be similarly motivated.

\section{Divorcement as an antitrust remedy.}

Assuming, however, that a group of integrated companies would be found to have violated the Sherman Act, as a combination with the effect of controlling or unduly influencing prices, Wolbert concludes that divorcement of pipe line ownership "does not necessarily follow."120 He contends that the effect of divorcement would probably be to raise pipe line rates and to weaken the service provided, with "little, if any, competitive gain on the part of independent refiners and jobbers, and detriment to independent producers and "wild catters." "127 The net result, he states, would be ligher prices to con-

123. Wolbert, AJienican Pipe Lines 45-8 (1952).

124. Id. at 48 .

125. See, e.g., the short connecting line built by the Wasatch Refinery, as reported in Minnelusa Oil Corp. v. Continental Pipe Line, 258 I.C.C. 41 (1944).

126. Wolrert, ANrerican Pipe LiNes 99 (1952).

127. Id. at 104. See also id. at 100-3. 
sumers, at least in the short run. Several arguments are advanced to support his conclusion.

Divorcement would harm the independent producer, Wolbert finds, because separate pipe line companies would be less aggressive than the present majorowned lines in reaching out quickly and effectively into new fields. ${ }^{128}$ Today in the competitive quest for supplies of crude, the major companies build gathering lines into producing areas as soon as they begin to show signs of a promising volume of production. While independently owned pipe lines would be as eager as the present pipe line owners to make money ${ }^{120}$ they might not be so willing to build before the reserve position of a new field is thoroughly established. ${ }^{130}$

Wolbert's reasoning seems to support a quite different thesis. For he contends, in effect, that pipe line ownership leads the major companies into uneconomic investments, which would not take place in a competitive environment. In their eagerness to tie up the output of a field-that is, to gain market and supply advantages as producers and purchasers in a new field-the major companies may throw in gathering lines before it has been established that the field's output will be sufficient to justify the investment. ${ }^{101}$ From the point of view of society, if not of the individual leaseholder in the field, it would surely be preferable to delay the investment in pipe until the field's prospective yield is more firmly established. Some students of the industry suggest that independently owned pipe line companies would be less vigorous than existing major companies in reaching fields where production prospects are good. It is difficult to see why this should be so. Experience in the natural gas industry does not indicate that independently owned pipe line companies are sluggish in building connections to new producing areas. Actually, independently owned pipe line companies would have motives for joining the wild-catters in a new field almost as quickly as the major companies do now. While they would not be concerned as purchasers of crude, they would have strong interests in gaining first access to a new field for the prospective transportation business. And the incentives for such prompt action would be increased if the building of pipe lines were to be put on a "certificate of necessity and convenience" basis, like many other forms of public utility investment.

The second half of Wolbert's argument is equally weak. He contends that divorcement would hurt the small producer because the major companies, not being committed to an existing field by pipe line ownership, might shift

128. Id. at 103.

129. Id. at 100 .

130. Id. at 103 .

131. Pogue, Economics of Pipe-Line Transportation in the Petroleum Industry 19 (1932) : "Pipe lines are doubtless open to criticism for providing oil fields too amply with transportation facilities, for under the urge of competition practically every oil area is over capacitated in this respect...." 
their purchases if cheaper oil became available elsewhere, whereas they now continue to buy oil in fields where they have placed pipe lines, even when they have to absorb small losses on gathering charges to do so. ${ }^{132}$ It is hardly a defense in the name of the competitive system that major companies may buy dear oil when they could get it more cheaply, because they have made a mistaken investment in pipe lines to a field which turns out badly. If production from a given field becomes comparatively expensive, any pipe line company, major owned or independent, would be under the same economic inducement to use its pipe line so long as any return above actual operating costs is earned on the carriage, or while operating losses are less than shutdown losses. Continued purchasing, and continued use of the facility beyond that point would involve an unjustified subsidy, often found in situations of vertical integration which turn out to have been poor investments.

Wolbert believes that independent jobbers could gain little if anything from pipe line divorcement. Their fate is linked to that of independent refiners, their chief suppliers. ${ }^{133} \mathrm{He}$ is convinced that independent refiners could not, as a practical matter, use independently owned pipe lines, for the reasons discussed on p. 895 supra, and therefore concludes that divorcement could not materially help jobbers. Since the argument with regard to independent refiners is unsound, the inference as to jobbers, which rests on it, falls as well.

The pipe lines themselves, according to Volbert, would face ruin and bankruptcy in the event of divorcement. For this dire conclusion he relies on the experience of two lines-the Crusader Pipe Line Company and the Prairie Pipe Line Company. They are hardly "the only precedents available."13s Several substantially common carrier pipe lines exist as part of the transportation network. And, more important, the experience of two lines which failed as independents competing with integrated lines, tied to particular major companies, is hardly a persuasive indication of what would happen if divorcement made all lines equally independent.

Moreover, the magnetic pull of the major companies is so strong that divorcement would not appreciably alter the prevailing pattern of industry organization.

"Assume that an independent pipe line company has been formed for the purpose of conducting a common carrier business. A small independent refiner (or group of refiners) approaches the pipe line company with a request for the construction of a pipe line. At the same time, a major oil company also is interested in having a pipe line laid to a differcnt location. The pipe line company naturally will be influenced by the volume and continuity of the business offered. Under the circumstances, the major oil

132. Wolbert, Aatrerican Pipe Lines 101 (1952).

133. Id. at $100-1$.

134. Id. at 102. Cf. id. at 43-5. See also note 98 sipro. 
company represents far greater assurance of future traffic, and consequently, will get the line. Multiply this incident by the number of major refiners, and the result will be very similar to the present location of long distance pipe lines." (Italics added.) ${ }^{\mathbf{1 3 5}}$

But there is no reason to assume that the independent refiner would not be located near the major company refinery, and therefore that the line could not serve both customers. The root of the problem is the location of refineries, and the possible development of independent refineries as well located as their major company rivals. On this phase of the matter, Wolbert's discussion is tantalizingly brief :

"The most persuasive argument in favor of divorcement is that it would create more competition between refiners for crude oil purchases and in the refinery gasoline market. However, it is contrary to common experience to believe that the mere divorcement of pipe lines would counteract the effect of large buying power. The independent producer would rather sell his oil to a steady, large volume buyer than to a fly-by-night who might give a premium today but shift his purchase the next day and never buy the producer's oil again. The independent pipe line owners would be just as inclined to favor their large customers, the major refiners, as would present pipe line management. In fact, due to their "open target" position, present pipe line companies frequently lean over backward to avoid discrimination against the smaller shippers. Even assuming arguendo that divorcement of pipe lines would cause independent refiners to spring up in the populated market centers, the effect of this would only be to foreclose the present independent refiners in the field, with the majors acquiring some of the field location business in the process."100

Yet it is only at this point that Wolbert considers one of the two serious antitrust issues presented by vertical integration in the oil industry, and the quoted paragraph represents his full comment on the problem.

Independent producers have been willing to sell to independent refiners, at a premium or otherwise, and have often complained when major companies took steps to prevent independent refiners from breaking through posted prices in a particular field. Nor is it immediately apparent that an independently owned pipe line would have to choose between its major and other customers, so long as pipe line capacity was adequate to serve the refineries of a given area. Of course the buying power of major companies would be formidable after pipe line divorcement, and, if legally permitted to do so, majors could offer inducements by way of long term contracts which others could not emulate. But such problems could not decisively affect the competitive position of new entrants into the refining business, assuming that they

135. Id. at 102-3.

136. Id. at 103-4. 
were located within easy reach of the pipe line, and had to pay the same transportation charge as the major companies.

If Wolbert's argument is correct, it raises another and more formidable possibility: that of the "illegal fruits" doctrine. ${ }^{137}$ The buying power of the existing large major companies would be a serious factor in the market even after pipe line divorcement, as he properly points out. That buying power would reflect the economic impact of their size-that is, the share of the market they occupy, and its potentialities for market control. Should that position of market influence be considered in part the result of many years of Sherman Act violation, in that major company growth was facilitated by pipe line rates so high as to enforce the sale of independently produced crude to major companies? We are inclined to disagree with Wolbert that the major companies would be able for long to retain their present position as crude purchasers in the event of divorcement. The market is not tightly enough organized for that result, and entry into the refining business should not be insuperably difficult.

If vertical integration permits the major companies, separately and collectively, to influence the market for crude, and by that influence (coupled with the pipe line rate structure) to handicap and to restrict independent entry into the refining business in the most economic locations, the remedy of injunction offers no cure. These consequences of pipe line ownership could not be viewed as an "abuse" of economic power. They must be considered a result of the size, structure and persistent parallel price policy of the major companies, which could only be dealt with by altering the structure of the industry.

In the light of his review of these diverse aspects of the pipe line problem, Wolbert makes two recommendations, which are in part ambiguous, and perhaps inconsistent. In the first place, he believes that rate regulation of major-owned pipe lines as common carriers, if it achieved "cost" rates, would eliminate the competitive advantage of major companies in refining and distribution. ${ }^{138}$ While this is no doubt a theoretical possibility, it is difficult to conclude that rate regulation has already reached that result, or, under existing procedures, that it could cut so fine a line. The cost structure of pipe line operations is such that the cost of transportation per barrel varies with the load factor on the line, so that "cost" rates could never be set in advance. Wolbert concludes, however, that if rates were reduced to the point where they represented only a reasonable return on carrier investment, the competitive inequality between pipe line owners and other shippers would be substantially eliminated. ${ }^{139} \mathrm{He}$ reaches this conclusion despite his view

137. Schine Theatres, Inc. v. United States, 334 U.S. 110, 127-30 (1948).

138. Wolbert, Asterican Pipe Lines 163 (1952).

139. For a similar view, see Mrinnelusa Oil Corp. v. Continental Pipe Line Co., 258 I.C.C. 41, 58 (1944) ("The establishment of the rates herein found reasonable will remove any unjust discrimination and undue prejudice and correct any violations of Section $6(7)$ that may have existed or may now exist."). 
that even in the event of pipe line divorcement the major companies would be so big as to be able to dominate the crude market. On the other hand, he favors regional antitrust suits in the different market regions of the country, and particularly in those areas "where effective competition appeared to be lacking," to attack both abusive and illegal practices, and structural defects which might lead to monopolistic results. He includes among the objectives of such suits "the undue use of leverage made possible by large aggregations of economic power."140 But it is not clear from his exposition whether he would recommend further examination of major company pipe line ownership as a possible factor giving the major companies an undue competitive advantage.

Part of the ambiguity in Wolbert's final conclusions stems from what we believe to be a mistaken premise as to the scope and standards of the antitrust laws. He assumes that the economist's social evaluation of an industry from the point of view of the public interest is identical with the judge's problem . in administering the antitrust laws. "Is the industry to be gauged by its structure or by its behavior and performance? It is submitted that a threefold test of structure, behavior and performance will furnish the best yardstick."141 The effects of this assumption permeate a good deal of his analysis, and color his conclusions in a variety of ways.

\section{The Economic Functions of Major-owned Pipe Lines.}

Pipe lines exist today as essential instruments in the drive of companies for assured sources of supply. So long as some large companies are vertically integrated, others cannot safely rely on the open market for crude. In part, the reason is inherent in the geology of the problem. If discovery should fall behind production, crude prices would rise and companien without their own oil would either be at a competitive disadvantage, or might even be out of business. Companies which hold their own oil land under lease are protected against possible shortage of crude, or increases in its price, although they correspondingly risk investment in oil resources which may turn out to be more costly than the oil which will become available on the market in the future. In view of the uncertainties of oil discovery, this is a risk most companies find it prudent to accept. In part, the reason behind the drive for oil acreage is implicit in the vertically integrated structure of the industry. Where some integrate, others must do likewise protectively. If none could integrate, all would be equally dependent on the crude market, and equally affected by changes in the real price of crude petroleum. Pipe lines must be understood in this context. No company wants to pay its competitors a premium for oil shipment if the competitors are getting trans-

140. Wolbert, American Pipe Lines 164 (1952).

141. Id. at 107. See pp. 859-64 supra. 
portation at cost. And each company would prefer not to be dependent on its competitors either for raw materials or for essential transportation service.

Two unquestioned facts are often advanced as decisive arguments against proposals for pipe line divorcement. Pipe line construction is inherently hazardous. While the great lines serving large consuming markets are reasonably sure of traffic, gathering lines to particular fields, or trunk lines based on a flow from particular areas, are not. Secondly, pipe lines have been operated as parts of large enterprises-"plant facilities"-organized to bring raw materials to refineries on schedule and in sufficient volume to permit the refineries to operate effectively. It is said that there are important cost advantages in the ownership of pipe lines and other transportation facilities by major oil companies.142 It is difficult, however, to find any specific indication of their character, beyond the obvious advantage of not paying the published tariff for carriage. ${ }^{143}$ The factor most frequently stressed is the ability of an integrated company to schedule its operations so as to keep pipe lines and refineries working as close to capacity as demand permits. Other industries-the automobile industry for example-operate complex massproduction manufacturing operations with decreasing vertical integration. The automobile companies have no difficulty in scheduling the procurement and delivery of the thousands of components used in the manufacture of cars without owning either the plants in which such parts are made or the trains and trucks which bring them to the factory. Indeed, they have found it an advantage to reduce the degree of their vertical integration, in order to be able to use their buying power in purchasing advantageously from many suppliers, and to avoid the risk of investment in a process or plant which

142. Pogtz, Econonics of Pipe-Line Transportation in tae Petrolevar Iandustiv 17-26 (1932). Chenery, International Petroleum Econonics in MImEsel. \& CHEJEty, ARABIAN OrL 145 (1949), explains vertical integration in the petroleum industry as in part motivated by the desire to achieve, through "combined planning," the lower unit costs made possible by utilization of pipe lines (and refineries) at close to full capacity, id. at 154 ; by "backward integration" to the source of supply when crude is expected to become scarce, $i d$. at 165-6; and by the quest for monopoly position, id. at 166-S. A study, Duricar, AlEx-

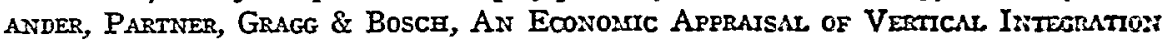
and Proposed Intoluntary Drorcenent of the Majos Functional Acivitues of INTEGRated Companies in the Petroleum Industry (1950) (made available through the courtesy of Oscar J. Dorwin, Esq., General Counsel of The Teras Company) puts primary emphasis on the assurance of supply of crude oil and of access to marlicts made possible by a company's ownership of its own transportation facilities. $I d$, at 78 . If divorcement could be carried out through sales to companies which could buy and operate pipe line systems as units and operate them satisfactorily, "there would probably be little change in the efficiency and only minor disruptions of the transportation service" Id. at 79. This study finds that no conclusions are possible as to the effect of vertical integration on the entry of independent refiners, until enquiries in the field establish, case by case, the motives of those who did and those who did not undertake the risks of the business. Id. at 241-3, 273.

143. 3 Bain, The Econouics of the Pactfic Const Pemoleusr Irousmy 17-8 (1947), and note 142 supra. 
may quickly become obsolete. Under these circumstances, they do not find the problem of planning the flow of parts needed for complex and continutous manufacturing operations in any sense insuperable. Refineries must have assurance of supplies delivered on time and in sufficient volume. If all oil companies were equally dependent on an open market for crude, and on common carrier transportation, it is hard to imagine why these essential conditions of successful refinery operation could not be satisfied.

Neither changes in pipe line rates nor other forces affecting the entry of independent firms into the refinery stages of the oil business seem so far to have substantially altered either the pattern of price formation or the degree of market influence of the major oil companies, at least in Eastern, Gulf Coast, and Mid-Continent market areas. The market power of the major companies continues to be conditioned by the existence and potential development of an independent "fringe" in the industry-independent refiners, jobbers or marketers who may be willing to shade prices, especially in the sale of secondary brands and of privately branded gasoline. ${ }^{144}$ As all observers of the industry have pointed out, a relatively small flow of independently marketed gasoline has been able to exert a considerable influence on the fragile and monopolistic "led" price structure. ${ }^{145}$ Thus far, neither the consent decree in the Atlantic case, nor the assertion of ICC power over pipe line rates, has opened the way for substantial changes in the market structure, or precipitated changes in price behavior. Despite the vigorous development of several smaller companies, the share of the majors in refining has slightly increased since the war. ${ }^{146}$ And most of the expansion in independent refining and marketing operations seems to have taken place under circumstances which permit the independents to depend on transportation other than major company owned pipe lines.

This is hardly conclusive evidence, except in the negative sense that the change in pipe line rates has not been sufficient to precipitate dramatic developments. But the time elapsed has been short, ${ }^{147}$ materials for refinery construction have not been available throughout the period, and costs have

144. Dirlam \& Kahn, supra note 32, at 828; Learned, Pricing of Gasoline: $A$ Case Study, 26 Harv. Bus. Rev. 723, 727 (1948) ; CAssady \& Jones, The Nature of CoMpetTtion in Gasoline Distribution at the Retall Level (1951) passim.

145. Rostow, op. cit. supra note 1 , at $57,82-4$. See materials cited in note 32 supra.

146. See pp. 889-91 supra.

147. Rates started to drop somewhat in 1934 and continued to drop until the war. Reduced Pipe Line Rates and Gathering Charges, 243 I.C.C. 115, 125 (1940). During the war pipe line rates could have no appreciable effect upon refinery construction, since military strategy dictated that new refineries be built at the sites of well located existing plants. Patron, op. cit. supra note 90, at 14-5: "[O]ver 80 per cent of the wartime expansion of facilities to manufacture needed petroleum products [were] made by expanding the facilities of the principal refiners." The drop in rates continued thereafter at least for some years. Reduced Pipe Line Rates and Gathering Charges, 272 I.C.C. 375, 380-2 (1948). See note 108 supra. 
been high. Profits have been great in the production phase of the industry. ${ }^{145}$ Nonetheless, one may conclude that if the old pipe line rate structure created a competitive advantage favoring the major companies, that competitive advantage seems to remain in a significant degree. Either rate changes have not been sufficient to affect the conditions governing entry; or not enough time has elapsed to permit such long-range forces to have their effect; or the monopolistic use of pipe line rates over a long period of time has built up an almost impregnable position for the major companies; or transportation costs don't have much to do with the problem anyway.

Some experienced members of the industry believe that the relatively low rate of growth of independent refining, despite the advance of a few larger and better located independent companies, indicates that disadvantages in transportation costs were never an important factor in determining the structure of the industry. They believe that the cost and high rate of obsolescence of refining plants, and the uncertainties of the market, have always been, and remain the elements which have determined the evolution and location of refining operations. Wolbert does not share this view, although his position on this point is not altogether consistent. He concludes that in the past the spread between pipe line costs and tariffs created a "monopolistic potential," which "accounts for" the adverse and non-competitive location of most independent refiners in the fields rather than in the markets. ${ }^{140}$ At the same time, he seems to find that independent refinery operations would have been disadvantageously located anyway. It seems altogether contrary to common experience in this and other industries, however, to conclude that substantial advantages in transportation costs do not in fact exert a powerful pressure on the location and market position of competing companies. The reports of the Interstate Commerce Commission are rich in evidence that transportation costs are a life and death matter to independent refiners, and largely determine their competitive opportunity. ${ }^{160}$

\section{The California Mother Hubbard Case.}

It is interesting in this connection that the complaint in the pending civil action of United States $v$. Standard Oil Company of California ${ }^{151}$ does not seek pipe line or other transportation divorcement of the defendant major companies, although it does pray for the divorcement of their marketing facilities. The case has been brought against the seven major oil companies operating in California, as a combination to monopolize the production, refin-

148. See Standard \& Poor's, Industry Surveys, "Oil" Nov. 22, 1951; Jan. 24, 1952; April 17, 1952.

149. Wolbert, Aurerican Pife Lines 53, 45, 48 (1952).

150. See, e.g., Increased Freight Rates, 276 I.C.C. 9, 86-8 (1949); Midland Cooperative Wholesale v. Abilene \& Southern Ry., 258 I.C.C. 75 (1944); Minnelusa Oil Corp. v. Continental Pipe Line Co., 258 I.C.C. 41 (1944).

151. Civil No. 11584-C (S.D. Cal. 1950); Complaint filed Mfay 12, 1950. 
ing and marketing of petroleum products in the states of California, Oregon, Washington, Nevada and Arizona. These states constitute an almost completely self-contained petroleum market, based on California crude production. The combination is asserted in the complaint to control production, through a Conservation Committee of California Oil Producers; to control the price at which independent producers sell to the majors in the oil fields, by a system of price posting which limits competition among the major companics as purchasers of oil; to control marketing (except for an area within a 30mile radius of Los Angeles harbor), through their ownership of substantially all pipe lines and marine transportation facilities, and of well over $80 \%$ of the refining capacity in the area; and through their organization of the wholesale and retail markets in the familiar system of identified outlets and price leadership, embracing over $80 \%$ of all outlets in direct contractual relations. The result of these operations, the complaint alleges, is that over $90 \%$ of the oil produced goes through the major companies, and close to that amount of the final products is marketed at prices under their control. The major companies, separately or together, are alleged to have bought up independent refineries or their product, or contracted for the use of their facilities, so as to remove their price influence from the market; to have forced independent producers to sell to them by refusing them pipe line facilities except on discriminatory terms; to have "squeezed" independent refiners by raising the price of crude without raising the price of gasoline, and otherwise to have coerced and discriminated against the independent sector of the market.

Several special features of the California scene distinguish the case from comparable problems that might arise in other markets. In the first place, the length of pipe line carriage is much shorter in California than in most other markets, so that the pipe line problem is materially different in character. ${ }^{152}$ Secondly, the pipe lines in California, being intrastate in scope, are not subject to federal regulation, and are alleged in the complaint to be regulated under California law in a perfunctory way. Thirdly, the major companies are charged with conducting a plan of private prorationing and production control, in the absence of state conservation legislation. ${ }^{163}$ Moreover, the system of product exchanges, and other forms of reciprocity and cooperation among major companies, may be more highly developed on the Pacific Coast than elsewhere.

The plan for the Pacific Coast industry proposed in the prayer for relief would enjoin the collective and individual "abuses" described in the complaint; dissolve and terminate all private production control activities; require future corporate acquisitions by the defendants to be approved by the court; make all existing pipe lines, storage, tanker, barge and marine terminal

152. 3 Batn, The Econonics of the Pacrfic Const Petroleuns Industry 46 (1947).

153. 2 BaIN, op. cit. supra note 152 , at c. 5 . 
facilities, and product exchange arrangements, available to any producer or refiner on non-discriminatory terms; limit purchase contracts to one year; enjoin any "through-put" contracts for the output of independent refiners, and price posting or other price programs designed to eliminate uncertainty in price formation; and require the major companies to get out of the marketing business, except for the wholesale business presently carried on at refineries and at marine terminals, and to be enjoined from establishing any plan to tie outlets or to control prices at wholesale and retail.

In his thorough study of the Pacific Coast petroleum industry, Bain concludes that pipe line divorcement may be less urgently required in California than in other markets as a step towards workable competition in the oil industry, ${ }^{154}$ but that even in the Pacific Coast market some means should be found to make pipe lines, and especially marine transport, freely available in order to facilitate the development of independent refineries now blocked by major company control of transportation facilities. ${ }^{155}$ Whether these ends could be sought more satisfactorily by divorcement than by the arrangements requested in the complaint in United States 2 . Standard Oil Company of California is a debatable point.

A decree of the type requested in that case would require the federal court, retaining jurisdiction, to become in effect a small scale Interstate Commerce Commission, keeping rates, charges of discrimination, the level of profits, and other aspects of the transportation business under continuous review. While the remedy would not be so "drastic" in form as divorcement, it might well prove to be infinitely more drastic in result. And it is not easy to see what public advantages would accrue to compensate for the disadvantages of continuous jurisdiction.

Furthermore, allowing the major companies to remain integrated up to the point of wholesale marketing might leave them with a large part of their present market power, unless independent refining companies developed more rapidly on the Pacific Coast than elsewhere once major-owned transport facilities were declared to be common carriers. For the major companies would operate in a market of a few large and several small sellers confronting many buyers, often smaller buyers. While marketing divorcement should lead to a reduction in the degree of waste which now characterizes petroleum distribution, marketing divorcement alone might leave the major companiesat least for some considerable period of time-in a position to slim the cream off the market more effectively than they can under the present system. Under such circumstances, they might really be able to charge high prices, and avoid the present excessive costs of distribution. The public might have to buy its road maps rather than receive them "free," and even pay directly for the use of rest rooms.

154. 3 id. at $45-7$.

155. Id. at 83-91. 


\section{Prospective Development in Independently Oremed Pipe Lines.}

One prospective change in the pattern of the industry could conceivably lead to a revision of prior judgments about the balance of forces governing the effective entry of non-integrated companies into both the refining and the marketing phases of the oil business. There are several projects pending for the establishment of independently owned pipe lines, which would connect the Gulf Coast area with North-Central and East Coast markets, and the West Texas area with the West Coast. And the first pipe line to reach the United States from Canada, while partially owned by major companies, is in many respects a common carrier enterprise. The first of these proposed domestic lines to receive approval from the Petroleum Administration for Defense is a plan for a products pipe line which would run from Beatumont, Texas, through parts of Louisiana, Arkansas, Tennessee, Kentucky, Ohio, Pennsylvania and New Jersey, terminating in Newark. ${ }^{150}$ The line would have significant capacity, despite its relatively small diameter, and its activities could substantially alter the geography of the industry, and the competitive position of many companies active in the area it would serve. If these projects are successful, further developments of this type might well presage significant changes. For strong independent pipe line companies, based on adequate supplies, should facilitate independent entry into refining and marketing, and weaken the price influence of the major companies, both in the crude and the products markets.

The economic basis for the United States Pipe Line proposal is the relatively greater recent increase in the cost of tanker than of pipe line operations, ${ }^{157}$ and the currently favorable relation between Gulf Coast and NorthCentral prices. Except during the war period, the movement of crude and products from the Gulf Coast to the Mid-Continent and North-Central areas has been marginal in character and relatively small in volume, consisting mainly of barge shipments. In recent years, Project Five pipe line from Port Arthur, Texas, to Helena, Arkansas, built during the war, and the Sinclair products pipe line system have added materially to the volume of light products reaching northern markets from the Gulf Coast. Increased steel production, coupled with suitable price differentials, has induced an increase in the volume of Gulf Coast residual fuel oil moving north by river barge. Further shifts of this character would seem to depend largely on a comparison of Gulf Coast prices with those in northern markets. There has been some instability in recent years

156. New York Herald Tribune, April 19, 1952, p. 3, col. 1. See Petty's Oil Letter, No. 371, Nov. 24, 1951. According to present plans, the line would be 16 inches in diameter to Cincinnati, 14 inches thereafter-a comparatively small installation. The operator would be the United States Pipe Line Company. The Petroleum Administration for Defense has recently approved the proposal in part, granting accelerated amortization privileges as to 25 per cent of the cost of the line, and reserving the question of steel until financial arrangements are completed.

157. See Standard \& Poor's, Industrial Surveys, "Ori," Nov. 22, 1951, p. 10. 
in the price relation between these markets. The United States Pipe Line project apparently rests on the judgment that pipe line costs can match tanker and barge costs, and that there will be a permanent market in the East Coast and North-Central regions for at least a marginal volume of products shipped by pipe line from the Gulf Coast area. The soundness of this judgment as a matter of the economics of location raises a substantial question, since refiners in the consuming areas to be served by the proposed line may well have a competitive advantage over Gulf Coast refiners using it. Some of the factors to be considered in making such a calculation are the comparative prices of crude oil at the well, the comparative costs of combined crude oil and product transportation, and the comparative price levels at the Gulf Coast and in markets to be served by the line not only for light products, but also for products such as lubricating and residual oils which could not move via pipe line. Furthermore, barge rates, while they have varied a good deal, are closely comparable with the rate structure contemplated for the United States Pipe Line project, and at some periods have been definitely below it. ${ }^{16 s}$

In addition to these factors, there is an increasing possibility that the high costs and high prices incident to present prorationing methods of production control in the southern and southwestern states will gradually permit Gulf Coast shipments to be displaced by foreign oil on the Atlantic seaboard. Indeed products manufactured on the eastern seaboard from foreign crude are beginning to move west, towards the Alleghenies, in significant volume.

Market wise, the interest attaching to the United States Pipe Line Company project is that it would be the first common carrier products line not owned by major company shippers. If it were operated as such, it could therefore link independent refineries in the Texas, Arkansas and Louisiana area to marketers in the North-Central and Eastern Seaboard districts of the United States. Whether this development increases the degree of competition in refining and marketing would depend largely on the way in which the pipe line is operated, as well as on the underlying relation between the full range of petroleum product prices in the markets thus linked.

In order to assure the possibility of successful operation, and a basis for their debt financing, the promoters of the United States Pipe Line are reported to be seeking 10-year contracts from shippers, guaranteeing an average daily minimum tender of at least 2,000 barrels for the period. Smaller minimum tenders, however, would pay a higher rate than larger ones. Mlinimum tender contracts would be made only up to 60,000 barrels a day, with no one contract covering more than 20,000 barrels. Spot shipments, and shipments above the minimum by shippers who have made minimum tender contracts, would be charged a higher rate than that applicable on shipments within a minimum tender contract. If the total offered under minimum tender con-

158. The Petroleum Administration for Defense anticipates an increase in refining in the North-Central region during the next few years, and a decline in products transportation to that area. Petroleus Adsinistration fos Derexse, Trazspostatua: of OIl 10 (1951). See also id. at $\$ 2$. 
tracts were greater than 60,000 barrels a day, each such shipper would receive its pro rata share of the 60,000 barrels. The proposed contracts also provide for reductions of all rates, both contract and spot, as the daily total volume of all shipments approaches the capacity of the line. The rate system would thus contain both quantity and contract rate discriminations: there would be several classes of rates, varying in proportion to quantities shipped within a short period of time; and a basic differential across the board in favor of shipments made pursuant to 10 -year minimum tender contracts.

The United States Pipe Line Company plan obviously raises some difficulties, under both the antitrust laws and the Interstate Commerce Act. It is commonly assumed in the oil industry that, because of the uncertain economic basis of the project, only major company shippers could undertake 10-year shipping commitments, especially at the lowest minimum tender rate. Given its route, the line would inevitably be dependent for some time at least on major company shippers. ${ }^{168 a}$ Assuming that there were no financial or other connections between major company shippers and the pipe line, and that in fact minimum tender contracts were freely available to all potential shippers, several questions emerge: (1) How would the validity of the rate differences, both within the class of shippers under minimum tender contracts, and between those shippers and spot shippers, be determined under the Interstate Commerce Act ?159 (2) Would such differences have to be justified by a cost analysis of the savings attributable to regular shipments of a given volume, or could they be evaluated from the point of view of their reasonableness as measures practically needed to induce the shipper commitments on the basis of which debt financing could be obtained? (3) Is there a risk that under some circumstances a group of major companies entering such contracts would constitute a combination in restraint of trade, if, for example, the effect of the shipment pattern established by the contracts was to give them a competitive advantage, based on the rate differentials, in a particular market reached by the line ?100

158a. Only about 12 per cent of the refining capacity in the Lake Charles-BeaumontHouston area, where the line is scheduled to start, is independent. Id. at 4.

159. It is assumed that since the Robinson-Patman Act, 49 STAT. 1526 (1936), 15 U.S.C. $\S 13$ (a) (1946), refers only to "commodities," it would have no direct application to the price of pipe line transportation, and that the legality of price arrangements under the Sherman Act could only be considered after their legality under the Interstate Commerce Act had been determined. Cf. Far East Conference v. United States, 342 U.S. 570 (1952).

This principle, however, would not necessarily be decisive in the situation being considered, since the effect of transportation rates on competition in the oil industry would not in all cases be settled by their legality vel non under the Interstate Commerce Act.

160. The Department of Justice is reported to have issued a "green-light" letter, indicating, on the basis of assumed facts, that it would not consider criminal proccedings under the Sherman Act, but expressing no opinion on problems raised by the plan under the Interstate Commerce Act. Petty's Oil Letter, Nov. 24, 1951. 
The legality of a frankly differential rate structure, of the type contemplated by the United States Pipe Iine, has never been evaluated by the Supreme Court in a comparable situation. The pipe line company would undoubtedly contend that without a rate inducement it could not obtain long-term contracts for shipment and that without such contracts it could not borrow the necessary funds. Such "through-put" agreements in variant forms are commonplace in pipe line financing. They are often made for lines owned and intended to be used by a major company, or a major company group, as part of the protection required by bank or insurance company lenders. Although shipper-owned lines are common carriers, and many carry some outside traffic, it is believed that none has hitherto employed a lower tariff for oil or products shipped under its through-put agreenents. Shipper stock: ownership or the equivalent, of course, provides some degree of similar advantage to the company which has made a long-term shipping commitment in such situations. The Interprovincial Pipe Line Company, operating from Edmonton, Alberta to Superior, Wisconsin, and backed by through-put agreements from Imperial Oil Company, a Standard of New Jersey subsidiary, and other shippers, raised part of its capital somewhat differently by issuing convertible debentures. ${ }^{161}$ And there are doubtless other forms of financing which should be available to an economically sound pipe line project without raising so basic an issue of common carrier practice as rate discrimination among shippers.

The rate advantage to shippers who have made 10-year minimum tender contracts would have to be considered primarily under Sections 1, 2 and 3 of the Interstate Commerce Act, in the ligint of their long and complex: history. ${ }^{162}$ Thus far, at any rate, the ICC has been most reluctant to allow any rate differences between shippers of the same commodity from the same point of origin to the same destination by the same line-haul, except on grounds of ascertainable differences in the actual cost of handling their shipments. In terms of Section 2, the Commission and the courts would have to consider, as a question of fact and of law, whether the rate system could be justified on the ground that spot and contract shipments would not involve the provision of "a like and contemporaneous service," and would not be made "under substantially similar circumstances and conditions." They would also have to determine under Section 3, whether the rate differential would constitute "an undue or unreasonable preference" to the long-term shipper, or "an undue and unreasonable discrimination" against spot shippers. And,

161. Interprovincial Pipe Line Company, Prospectus for New Issue of $\$ 17,000,000$ $4 \%$ Convertible Sinking Fund Debentures, Series A, filed with Secretary of State of Canada, Sept. 21, 1949.

162. $\$ 1,41$ Stat. 474 (1920), 49 U.S.C. $\$ 1$ (1946); $\$ 2,24$ StAt. 379 (1887), 41 StAt. $479(1920), 49$ U.S.C. $\$ 2$ (1946); $\$ 3,24$ StAT. 380 (1887), 41 SrAT. 479 (1920), 49 U.S.C. $\$ 3$ (1946). And also the Elkins Act, supplementing $\$ 2,32$ STAт. 847 (1903), 49 U.S.C. $\$ 41$ (1946) (providing remedies for a "rebate, concession or discrimination ... whereby ... [an] advantage is given or discrimination is practiced"). 
more broadly, the rate system would have to be evaluated as "just and reasonable" under Section 1.

The meaning of these statutory phrases has been thrashed out in a variety of situations. Thus a discrimination between car-load and less-than-carload shippers of the same commodity is commonly allowed, on the ground that the costs of handling each shipment differ. ${ }^{163}$ Similar evaluation of cost differences dominates the decisions sometimes allowing, and sometimes denying, multiple-car rates below car-load rates. ${ }^{164}$ Where intercarrier competition is in issue, the Commission has been instructed to go further, and to weigh possible cost justifications for volume rates, on the one hand, against the actual discriminatory effects of rate differences among shippers, and the effect of differential rates on intercarrier competition, on the other. ${ }^{105}$ So far there is little guidance as to how these somewhat different elements are to be balanced in specific cases, beyond the strong tradition in favor of equal rates for shippers similarly placed. While promotional rates, and rates designed to secure traffic which would not otherwise have come to the carrier, have had some scope, no such cases have really approached the problem raised by the proposed United States Pipe Line. Perhaps the closest analogy was the practice of giving special rates to freight forwarders, which the ICC and the Supreme Court found to be a discrimination violating Section 2, in the absence of special legislation. ${ }^{166}$ Furthermore, even under the new legislation authorizing special rate consideration for freight forwarders, rate differentials based on an annual volume of shipments are unlawful as discriminatory. The Commission has said, "There is no justification for applying a special rate based upon the aggregate amount of freight forwarded by a patron during a given period of time. The Commission has repeatedly held that such rates are in the nature of a discount in favor of large shippers or consignees, and, hence, unlawful."167

163. Eastern-Central Motor Carrier Assn. v. United States, 321 U.S. 194, 205 (1944) ; ICC v. Del. L. \& W. R.R., 220 U.S. 235 (1911); Thurber v. N.Y.C. \& H.R.R., 3 I.C.C. 473 (1890). See III-B Sharman, The Interstate Comarerce Commission 395-413 (1936).

164. Compare Molasses from New Orleans, La., to Peoria and Pelcin, Ill, 235 I.C.C. 485 (1939), with Petroleum Rail Shippers Assn. v. Alton \& Southern R.R., 243 I.C.C. 589 (1941). Moreover, even where multiple-car or other volume rates are allowed, commonly to meet other carrier competition, the Commission has been meticulous to insist on evidence that the spread allowed for the larger quantity shipment is just and reasonable, in the light of cost differences. Limestone from Prairie du Rocher, Ill., to Baton Rouge, 276 I.C.C. 381 (1949). Petroleum Products from Salt Lake City to Spokane, 273 I.C.C. 736, 743-4 (1949); Limestone to Baton Rouge, 270 I.C.C. 584,590 (1948).

165. Eastern-Central Motor Carrier Assn. v. United States, 321 U.S. 194 (1944). Sec also Willingham v. Seligman, 179 F.2d 257 (5th Cir. 1950).

166. United States v. Chicago Heights Trucking Co., 310 U.S. 344 (1940). Sce also ICC v. Balt. \& Ohio R.R., 225 U.S. 326 (1912) (rate discrimination illegal between coal destined for sale and coal to be used by railroad as fuel).

167. Forwarder Rates Conditioned upon Aggregates of Tonnage, Western Frcight Association, 264 I.C.C. 225,233 (1945). The Commission warned that annual rate adjust- 
Both the contract rate differential and the quantity discount features of the United States Pipe Line proposal squarely challenge the rule against rate discrimination, one of the central themes of the Interstate Commerce Act. Although not directly relevant to the problem under Section 2 of the Interstate Commerce Act, the factual validity of the argument that at least a contract rate differential is necessary to facilitate the financing of non-shipper-owned pipe lines would require careful scrutiny. In any event, the potential impact of differences in transportation cost on competition in the oil industry is so serious as to make any such departures from the consistent interpretation of the Interstate Commerce Act, whether by judicial decision or legislation, most dubious policy. If rate differentials were approved in this instance, there would be no ground under Section 2 for denying like privileges to major-owned common carrier pipe lines.

Some aspects of the legality of the proposed rate structure of the United States Pipe Line would have to wait for resolution until an actual state of facts would permit the Commission and the courts to examine actual costs of shipment, and the effects of the rate system on competition among carriers and among shippers. Meanwhile, such difficulties may delay the completion, at least in this instance, of the highly desirable experiment of non-shipperowned pipe line.

\section{Conclusion}

All things considered, the oil industry is one of the most striking instances in our history of the success of the antitrust laws, and of the driving force, creativeness and vitality of American business. The interaction of these two powerful elements in social experience produced first the simple oil monopoly which was dissolved in 1911, and now, forty years and at least a hundred law suits later, the familiar industry picture of today, a relatively small and stable group of very large corporations, a group of smaller majors, and a vast company of independents, wildcatters, engineering firms, research consultants, brokers, jobbers, service station operators and assorted bit-players.

ments also violated the provisions of the Elkins Act, id. at 234. The position talien, the Commission recalled; has been consistently held since the first volume of its Reports, Providence Coal Co. v. Providence and W. R.R., 1 I.C.C. 107 (1S87) (discounts for annual shipments of more than 30,000 tons illegal). See also, Books, Drugs and Cotton Goods from New York to Chicago, 256 I.C.C. 85 (1943); In the Miatter of Container Services, 173 I.C.C. 377 (1931) ; Private Wire Contracts, 50 I.C.C. 731, 757 (1918) ("We have frequently stated that the so-called wholesale theory has no proper place in the rates of common carriers."). The long-term minimum tender contracts raise antitrust problems quite distinct from the legality under the Interstate Commerce Act toth of the rate difference for contract shippers and of the rate advantage for quantity shipments, spot or contract. Commitments which deny competitors access to a substantial segment of a market have recently been scrutinized severely by the Supreme Court (sse cases citcd in note 33 stipra). Presumably the considerations underlying these decisions would apply with particular force to the facilities of a common carrier. Cf. Gamco, Inc. v. Providence Fruit \& Produce Bldg., 194 F.2d 484 (1st Cir. 1952). 
Few would deny that today's oil industry comes closer to serving the general interest than the industry of forty years ago. It is turbulent, active, and aggressive, with a good deal of room for change and growth.

That the industry is more competitive than it was is not evidence that it is yet as competitive as it could be or should be, given the broad purposes of the Sherman Act. The industry structure has large elements both of competition and of monopoly power. And its technology and geology would permit a wide range of changes without loss of efficiency or research potential. We believe that the judicious further application of antitrust policy could do a great deal to ease entry into the refining-and therefore the marketing-phases of the industry, and to eliminate some of the wastes which now characterize industry procedure. Organized markets dominated by a few large sellers will normally engage in systematic price leadership, and injunctions against such practices will normally be ineffective, since they represent the consequences of the size and self-interest of large sellers (and buyers) who together constitute effective control of supply. Where, as in the oil industry, production is also limited to administrative estimates of market demand, "shortage" of oil, and uncertainty of access to supply are bound to be common difficulties in periods of rising economic activity.

The vertical integration of the large companies, despite some pipe line rate reductions, still seems to function as the key factor permitting them to influence the price of crude, to limit the amount of independently refined crude reaching consuming markets, and thus to maintain a semblance of order in the pricing of final products. Although majors in some areas supply pricecutting independent jobbers, they normally do so when the independent keeps no more than an approved differential between secondary brands or privately branded gasoline and the major company's primary brands. ${ }^{168}$ While it will take more field studies to establish the point definitively, our impression is that it is rare to find an established major company simultaneously distributing in a market area and selling to aggressive and large-scale price-cutters. That this has happened to a limited extent in Los Angeles is recognized even in the complaint in United States $v$. Standard Oil Company of California. But it has not been shown to be the normal pattern of price experience either there, or in most other gasoline markets. Price discipline normally results from the basic fact of dependence for supplies. The independent jobber or marketer who obtains his product from a major company in most cases conducts his price policy within the limits of what he thinks his supplier would tolerate. A word, a telephone call, a rumor heard by others is usually enough to produce results, since the purchaser under these circumstances fears all sorts of difficulties. The major company supplier may not have the slightest intention of cutting off his supplies, or his credit, or inflicting other forms of punishment. But such things happen. The fears are real, and produce results. The aggressive price cutter is almost never exclusively supplied by a major company.

168. See, e.g., CaSsady \& Jones, op. cit. supra note 32, at 116-27. 
Professors Dirlam and Kahn suggest that the partial disintegration of major company retail operations, accomplished in some markets by chain store taxes and other measures, has led the major companies to increase pressure on retail prices by selling to price-cutters, thus weakening the price structure significantly. ${ }^{160}$ This contention hardly bears on the desirability of pipe line ownership by the major companies. If its factual basis were well established, it would apply only to the partial integration of large-sale refining and distribution operations. "And of course an even greater degree of price instability in retail markets would be produced if the number of wholesale sellers were increased, through the effective expansion of significant independent refining operations. Under such circumstances, there is no reason to suppose that the large class of jobbers could organize effectively to achieve their heart's desire- $a$ stable system of fixed prices and wide margins. They would be too numerous to do the job, without legislation. And even direct "fair trade" legislation, as experience in the liquor industry indicates, is not easy to enforce, where buyers and sellers are numerous.

Viewed broadly, there are three major areas where the present organization of the oil industry presents important opportunities for the reduction of longrun social costs. The system of controlling production, through state and federal cooperation in the administrative limitation of output, has some of the worst features of the AAA program, without even its checks and balances. ${ }^{170}$ Within a wide zone, the oil producing states themselves determine the level of crude oil prices, and do so in ways which involve a needlessly large number of wells, and therefore a needlessly high consumption of steel, manpower and the underground pressures of the oil pools. Especially if the potential economies of secondary recovery are to be realized, unitization is more urgently required than ever. With unitization, the case for limiting output to "market demand" would disappear. ${ }^{171}$ Secondly, the method of distributing oil products is unjustifiably expensive-in its price procedures, its advertising outlays, and in the number and cost-level of the service stations It seems to produce. These consequences of oligopoly in selling are deeply rooted in the structure of the industry, in the relative size and historic relations of the major companies, and in the strategic power over prices inherent in their vertical integration. Thirdly, there is the problem re-examined in the present article-that of entry into the refining stages of the business. While there have been considerable shifts in recent years in the scale and location of independent refining operations, the experience of independent refining companies sharply raises the question whether the ownership of pipe lines by major companies, in the context of the oil industry and its pricing methods, still constitutes a barrier to the competitive development of independent oil refining. If this barrier were removed by pipe line divorcement, Bain has said,

169. Dirlam \& Kahn, op. cit. stipra note 32 , at $851-2$.

170. Rostow, op. cit. supra note 1 , at cc. 5, 6, 13.

171. Rostow, A Reply, 57 J. PoL. Econ. 60, 61-3 (1949). 
"society would probably not lose much by it and might gain enough to make it worth while."172 He finds that vertical integration was prompted in the oil industry by market factors rather than by considerations of technical efficiency, and that its impact on technical efficiency is "approximately neutral." On the other hand, its impact on the effectiveness with which the market carries out its social functions is far from neutral. Vertical integration by the older companies was a step towards achieving power over price, and for the newer ones a defensive response to the facts of life in an oligopoly..$^{173}$ Under these circumstances, public policy could intervene constructively in the interest of organizing a freer and more efficient form of competition in the oil industry.

In the oil industry, two aspects of vertical integration seem to result in farreaching control over price: integration between refining and transportation, and between refining and marketing. The ownership and leasing of oil lands by major companies of course give the owners a substantial profit, when those properties turn out well. But such profits are quasi-rents which do not ats such affect the cost structure or competitive position of the integrated companies. On the other hand, ownership of transportation facilities, at least in situations where competing companies must use those facilities, permits the integrated companies two substantial advantages: (1) it often facilitates their efforts to obtain leases, or otherwise to tie-up the output of the particular producing area served by their pipe line system, perhaps in the ancient sense of "forestalling,"174 and (2), even more clearly, it puts the major companies in a strong position as purchasers of the output of the field. And the integration of refining and of marketing facilities, by ownership, contract, or less sharply defined relationships, gives the group of major companies in most markets the capacity to pursue an effective policy of price leadership and of non-price competition. The result of both these aspects of the structure of the industry is to create an insistent drive on the part of substantial independent companies to integrate backwards, in order to obtain assured sources of supply, and to integrate forwards, to gain assured outlets. Smaller independent companies can profitably exist as supplementary facilities of the majors, to supply then with the products they need to meet the inevitable margin of error in their calculations. But real growth in the independent sector of the market is extraordinarily difficult, perhaps impossible, without "defensive" integration against the consequences of the fact that so large a share of production and transportation is effectively foreclosed to the independent company by the existing structure of the industry.

172. Bain, A Rejoinder, 57 J. PoL Econ. 68, 69 (1949).

173. 3 BAIN, op. cit. supra note 152 , at 17-8.

174. See Schueller's important article, The New Antitrust Illegality Per Se: Forestalling and Patent Misuse, 50 CoL. L. REv. 170 (1950); Comment, Vertical Forestalling under the Antitrust Laws, 19 U. oF CHI. L. Rev. 583 (1952). 